\title{
LEVEL II SCOUR ANALYSIS FOR BRIDGE 7 (BRATTH00120007) on TOWN HIGHWAY 12, crossing HALLADAY BROOK, BRATTLEBORO, VERMONT
}

Open-File Report 98-074

Prepared in cooperation with

VERMONT AGENCY OF TRANSPORTATION

and

FEDERAL HIGHWAY ADMINISTRATION

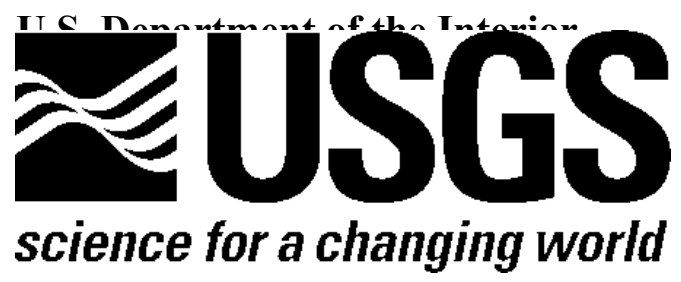




\section{LEVEL II SCOUR ANALYSIS FOR BRIDGE 7 (BRATTH00120007) on TOWN HIGHWAY 12, crossing HALLADAY BROOK, BRATTLEBORO, VERMONT}

By RONDA L. BURNS and ERICK M. BOEHMLER

U.S. Geological Survey Open-File Report 98-074

Prepared in cooperation with

VERMONT AGENCY OF TRANSPORTATION

and

FEDERAL HIGHWAY ADMINISTRATION 


\title{
U.S. DEPARTMENT OF THE INTERIOR BRUCE BABBITT, Secretary
}

\author{
U.S. GEOLOGICAL SURVEY
}

Thomas J. Casadevall, Acting Director

For additional information write to:

District Chief

U.S. Geological Survey 361 Commerce Way

Pembroke, NH 03275-3718
Copies of this report may be purchased from:

U.S. Geological Survey

Branch of Information Services

Open-File Reports Unit

Box 25286

Denver, CO 80225-0286 


\section{CONTENTS}

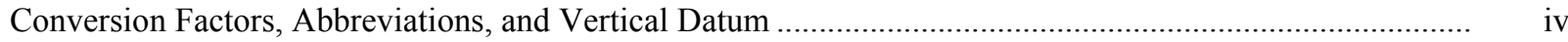

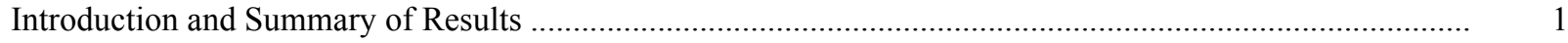

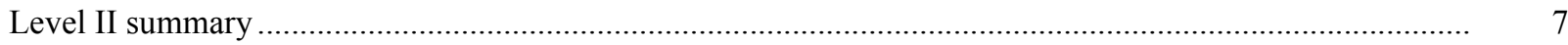

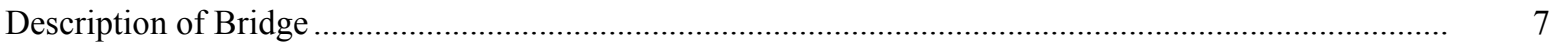

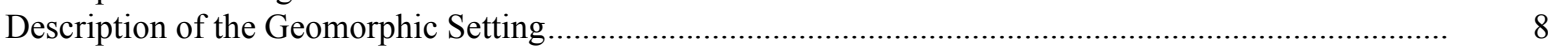

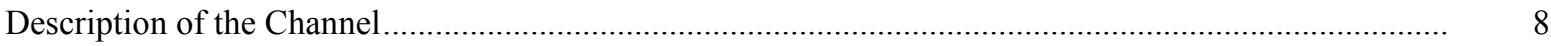

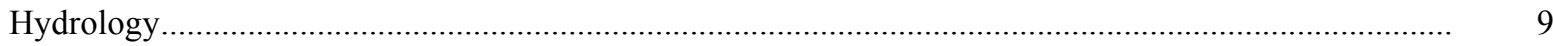

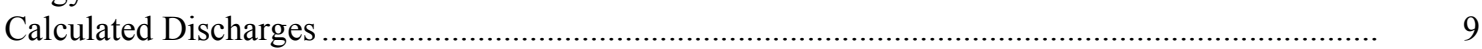

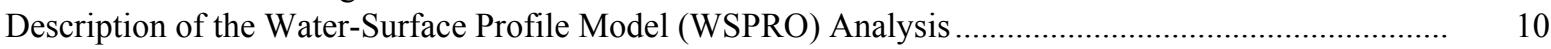

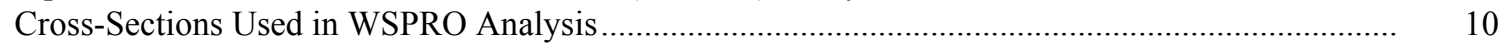

Data and Assumptions Used in WSPRO Model ........................................................................ 11

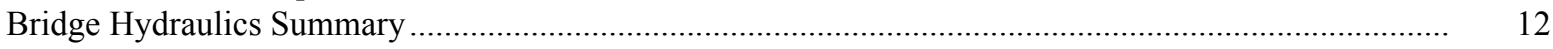

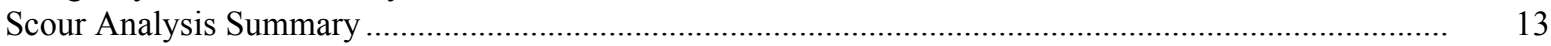

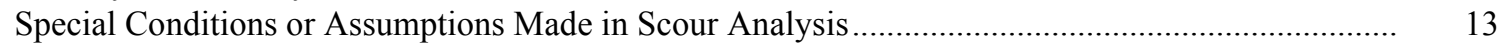

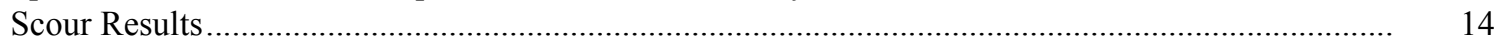

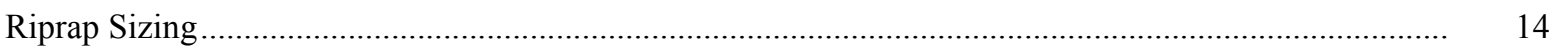

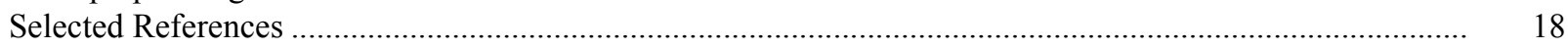

Appendices:

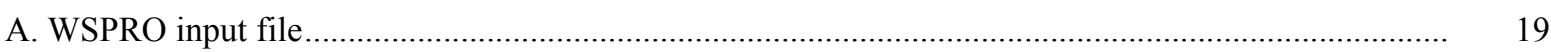

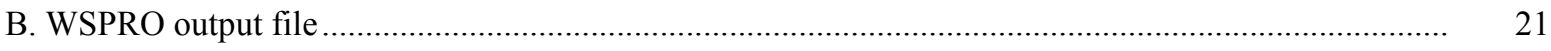

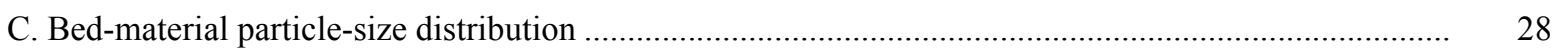

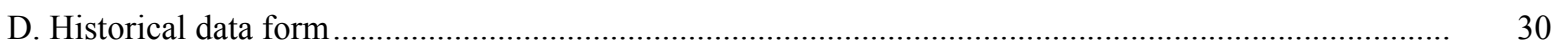

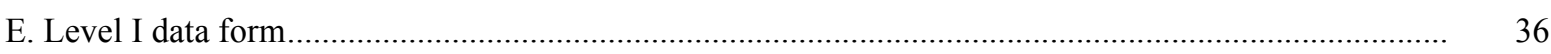

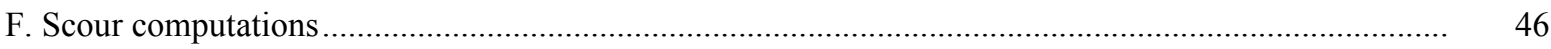

\section{FIGURES}

1. Map showing location of study area on two USGS 1:25,000 scale maps

2. Map showing location of study area on Vermont Agency of Transportation town highway map .....

3. Structure BRATTH00120007 viewed from upstream (August 14, 1996).

4. Downstream channel viewed from structure BRATTH00120007 (August 14, 1996)........................... 5

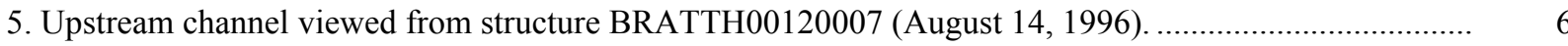

6. Structure BRATTH00120007 viewed from downstream (August 14, 1996).

7. Water-surface profiles for the 100- and 500-year discharges at structure BRATTH00120007 on Town Highway 12, crossing Halladay Brook, Brattleboro, Vermont

8. Scour elevations for the 100- and 500-year discharges at structure

BRATTH00120007 on Town Highway 12, crossing Halladay Brook,

Brattleboro, Vermont.

\section{TABLES}

1. Remaining footing/pile depth at abutments for the 100-year discharge at structure

BRATTH00120007 on Town Highway 12, crossing Halladay Brook,

Brattleboro, Vermont

2. Remaining footing/pile depth at abutments for the 500-year discharge at structure

BRATTH00120007 on Town Highway 12, crossing Halladay Brook,

Brattleboro, Vermont 


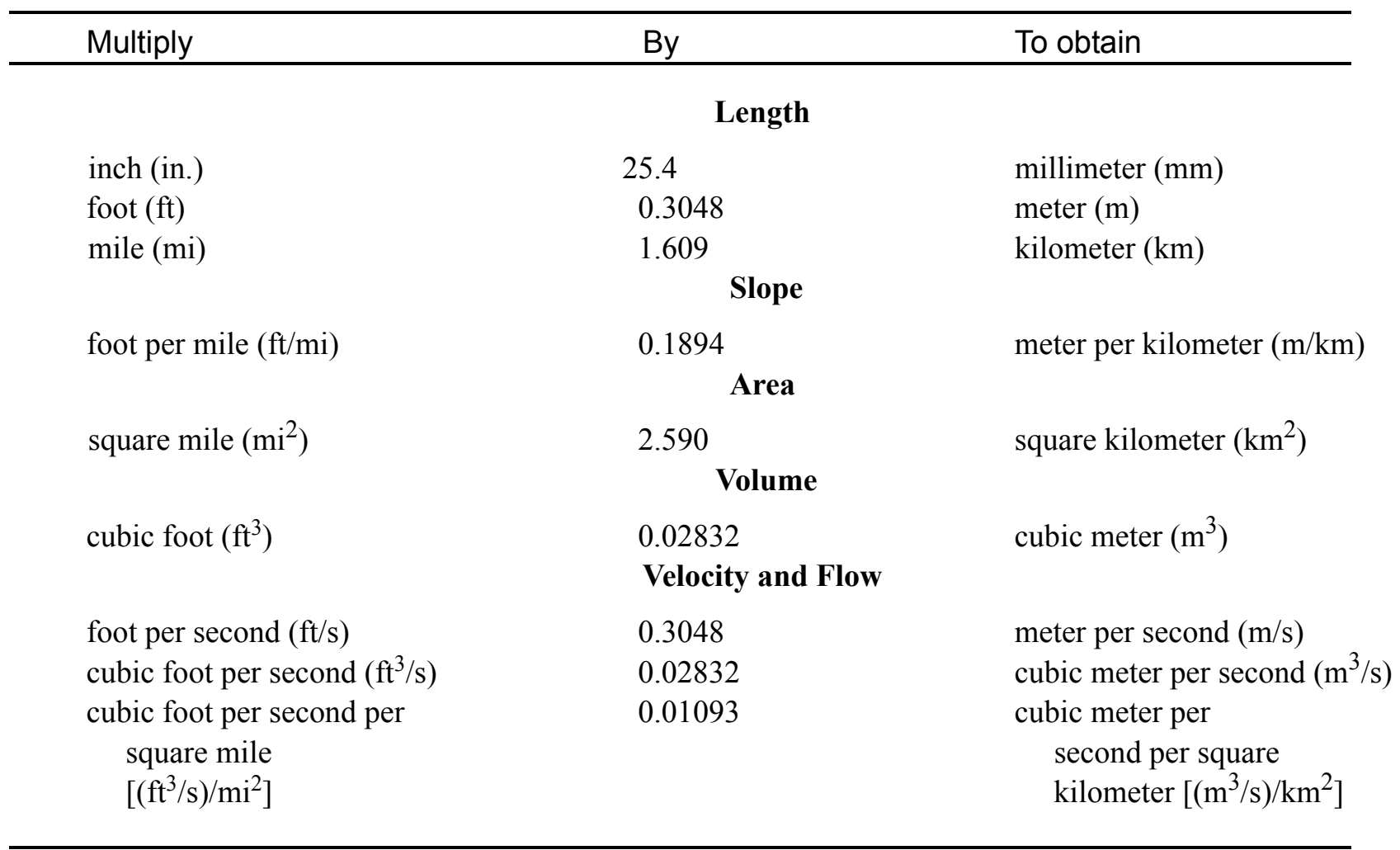

\section{OTHER ABBREVIATIONS}

$\begin{array}{lrlr}\text { BF } & \begin{array}{r}\text { bank full } \\ \text { cfs }\end{array} & \text { LWW } & \text { left wingwall } \\ \mathrm{D}_{50} & \text { median feet per second } & \text { Max } & \text { maximum } \\ \mathrm{DS} & \text { main channel } \\ \mathrm{elev} & \text { downstream } & \text { RAB } & \text { elevation } \\ \mathrm{f} / \mathrm{p} & \text { RABUT } & \text { right abutment } \\ \mathrm{ft} & \text { flood plain } & \text { RB } & \text { face of right abutment } \\ \mathrm{ft} / \mathrm{ft} & \text { square feet } & \text { ROB } & \text { right bank } \\ \text { FEMA } & \text { feet per foot } & \text { RWW } & \text { right overbank } \\ \text { FHWA } & \text { Federal Emergency Management Agency } & \text { TH } & \text { right wingwall } \\ \text { JCT } & \text { Federal Highway Administration } & \text { UB } & \text { town highway } \\ \text { LAB } & \text { junction } & \text { US } & \text { under bridge } \\ \text { LABUT } & \text { left abutment } & \text { USGS } & \text { upstream } \\ \text { LB } & \text { face of left abutment } & \text { VTAOT } & \text { Vermont Agency of Transportation } \\ \text { LOB } & \text { left bank } & \text { WSPRO } & \text { water-surface profile model } \\ & \text { left overbank } & \text { yr } & \text { year }\end{array}$

In this report, the words "right" and "left" refer to directions that would be reported by an observer facing downstream. Sea level: In this report, "sea level" refers to the National Geodetic Vertical Datum of 1929-- a geodetic datum derived from a general adjustment of the first-order level nets of the United States and Canada, formerly called Sea Level Datum of 1929.

In the appendices, the above abbreviations may be combined. For example, USLB would represent upstream left bank. 


\title{
LEVEL II SCOUR ANALYSIS FOR BRIDGE 7 (BRATTH00120007) ON TOWN HIGHWAY 12, CROSSING HALLADAY BROOK, BRATTLEBORO, VERMONT
}

\author{
By Ronda L. Burns and Erick M. Boehmler
}

\section{INTRODUCTION AND SUMMARY OF RESULTS}

This report provides the results of a detailed Level II analysis of scour potential at structure BRATTH00120007 on Town Highway 12 crossing Halladay Brook, Brattleboro, Vermont (figures 1-8). A Level II study is a basic engineering analysis of the site, including a quantitative analysis of stream stability and scour (Federal Highway Administration, 1993). Results of a Level I scour investigation also are included in appendix E of this report. A Level I investigation provides a qualitative geomorphic characterization of the study site. Information on the bridge, gleaned from Vermont Agency of Transportation (VTAOT) files, was compiled prior to conducting Level I and Level II analyses and is found in appendix D.

The site is in the New England Upland section of the New England physiographic province in southeastern Vermont. The $5.53-\mathrm{mi}^{2}$ drainage area is in a predominantly rural and forested basin. In the vicinity of the study site, the surface cover is pasture while the immediate banks upstream have some trees and shrubs.

In the study area, Halladay Brook has an incised, straight channel with a slope of approximately $0.01 \mathrm{ft} / \mathrm{ft}$, an average channel top width of $29 \mathrm{ft}$ and an average bank height of $5 \mathrm{ft}$. The channel bed material ranges from sand to cobble with a median grain size $\left(\mathrm{D}_{50}\right)$ of $66.6 \mathrm{~mm}(0.219 \mathrm{ft})$. There is also a bedrock outcrop in the channel upstream. The geomorphic assessment at the time of the Level I and Level II site visit on August 14, 1996, indicated that the reach was stable.

The Town Highway 12 crossing of Halladay Brook is a 28-ft-long, two-lane bridge consisting of one 25-foot concrete slab span (Vermont Agency of Transportation, written communication, April 5, 1995). The opening length of the structure parallel to the bridge face is $21.9 \mathrm{ft}$. The bridge is supported by vertical, laid-up stone abutments with laid-up stone wingwalls, except for the downstream right wingwall which is concrete. The channel is skewed approximately 55 degrees to the opening while the opening-skew-to-roadway is 45 degrees. 
A scour hole $1.0 \mathrm{ft}$ deeper than the mean thalweg depth was observed along the right abutment and downstream right wingwall during the Level I assessment. The scour protection measures at the site included type- 1 stone fill (less than 12 inches diameter) at the downstream right wingwall, type- 2 stone fill (less than 36 inches diameter) along the upstream right bank, and a type-5 laid-up stone retaining wall on the upstream left bank. Additional details describing conditions at the site are included in the Level II Summary and Appendices D and E.

Scour depths and recommended rock rip-rap sizes were computed using the general guidelines described in Hydraulic Engineering Circular 18 (Richardson and Davis, 1995) for the 100- and 500-year discharges. In addition, the incipient roadway-overtopping discharge was determined and analyzed as another potential worst-case scour scenario. Total scour at a highway crossing is comprised of three components: 1) long-term streambed degradation; 2) contraction scour (due to accelerated flow caused by a reduction in flow area at a bridge) and; 3 ) local scour (caused by accelerated flow around piers and abutments). Total scour is the sum of the three components. Equations are available to compute depths for contraction and local scour and a summary of the results of these computations follows.

Contraction scour for all modelled flows ranged from 1.1 to $3.4 \mathrm{ft}$. The worst-case contraction scour occurred at the 100-year discharge. The left abutment scour ranged from 1.7 to $2.8 \mathrm{ft}$. The worst-case left abutment scour occurred at the 500 -year discharge. The right abutment scour ranged from 4.6 to $4.8 \mathrm{ft}$. The worst-case right abutment scour occurred at the 500-year discharge. Additional information on scour depths and depths to armoring are included in the section titled "Scour Results". Scoured-streambed elevations, based on the calculated scour depths, are presented in tables 1 and 2. A cross-section of the scour computed at the bridge is presented in figure 8. Scour depths were calculated assuming an infinite depth of erosive material and a homogeneous particle-size distribution.

It is generally accepted that the Froehlich equation (abutment scour) gives "excessively conservative estimates of scour depths" (Richardson and Davis, 1995, p. 46). Usually, computed scour depths are evaluated in combination with other information including (but not limited to) historical performance during flood events, the geomorphic stability assessment, existing scour protection measures, and the results of the hydraulic analyses. Therefore, scour depths adopted by VTAOT may differ from the computed values documented herein. 


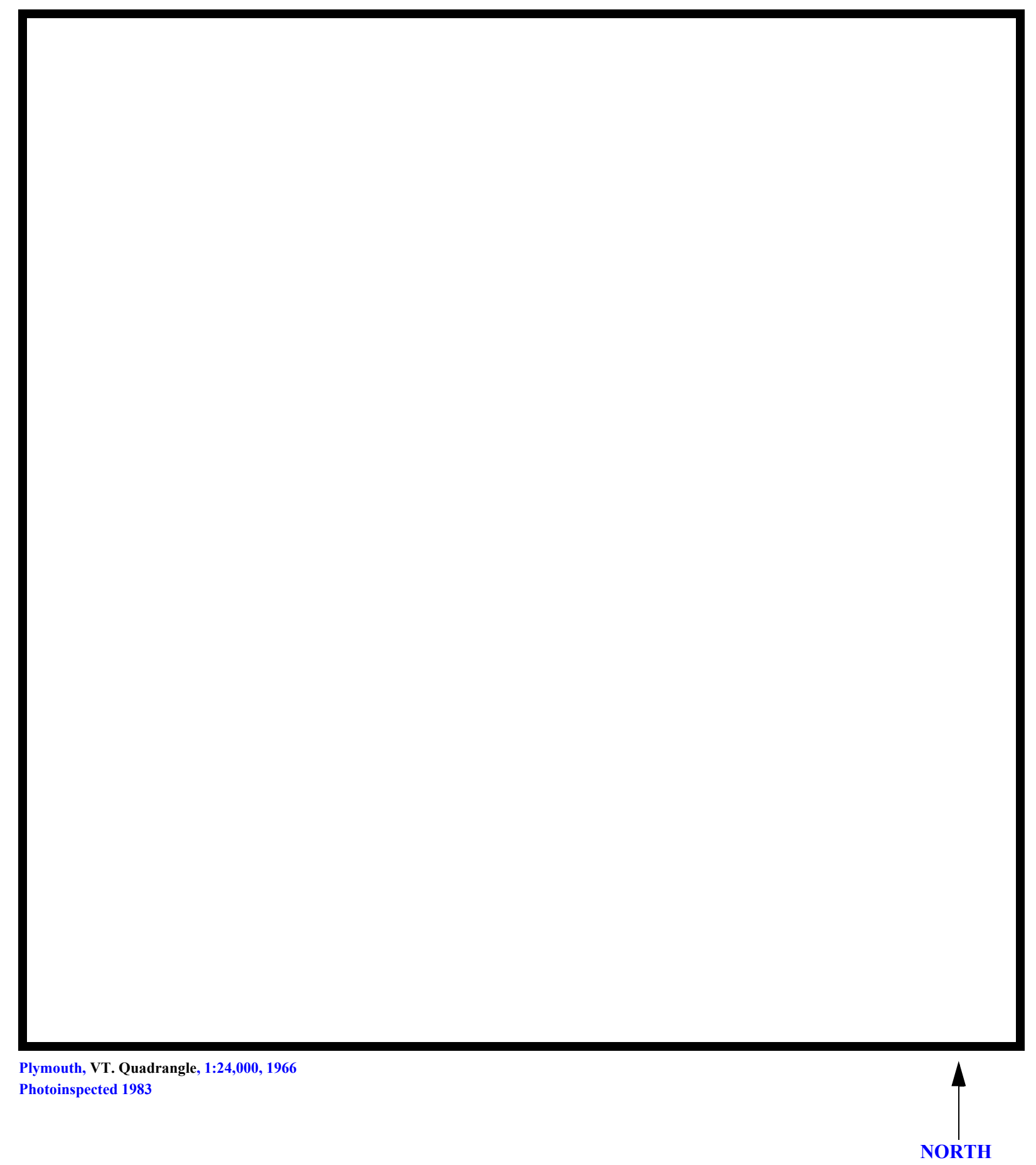

Figure 1. Location of study area on USGS 1:24,000 scale map. 
Figure 2. Location of study area on Vermont Agency of Transportation town highway map. 

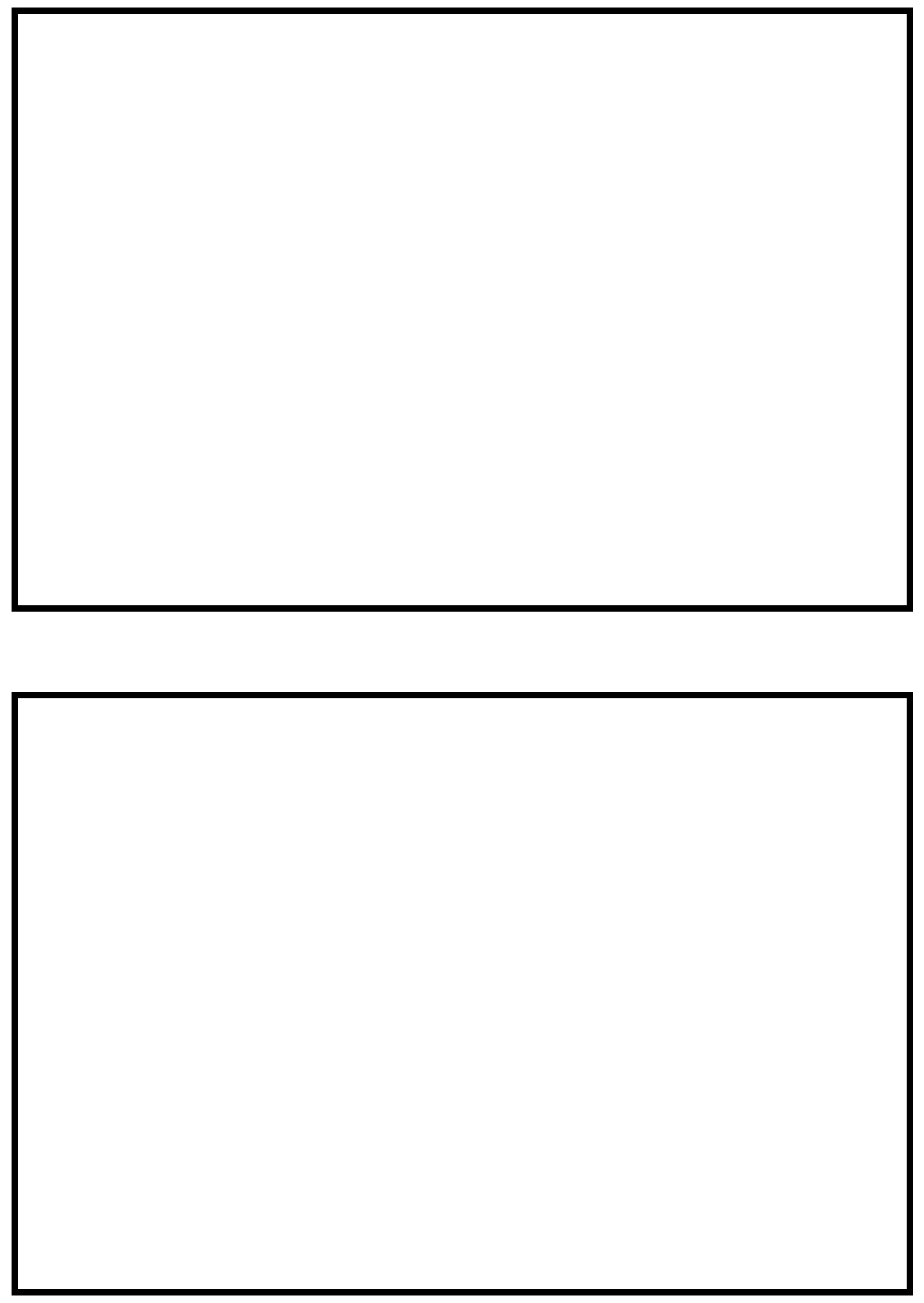

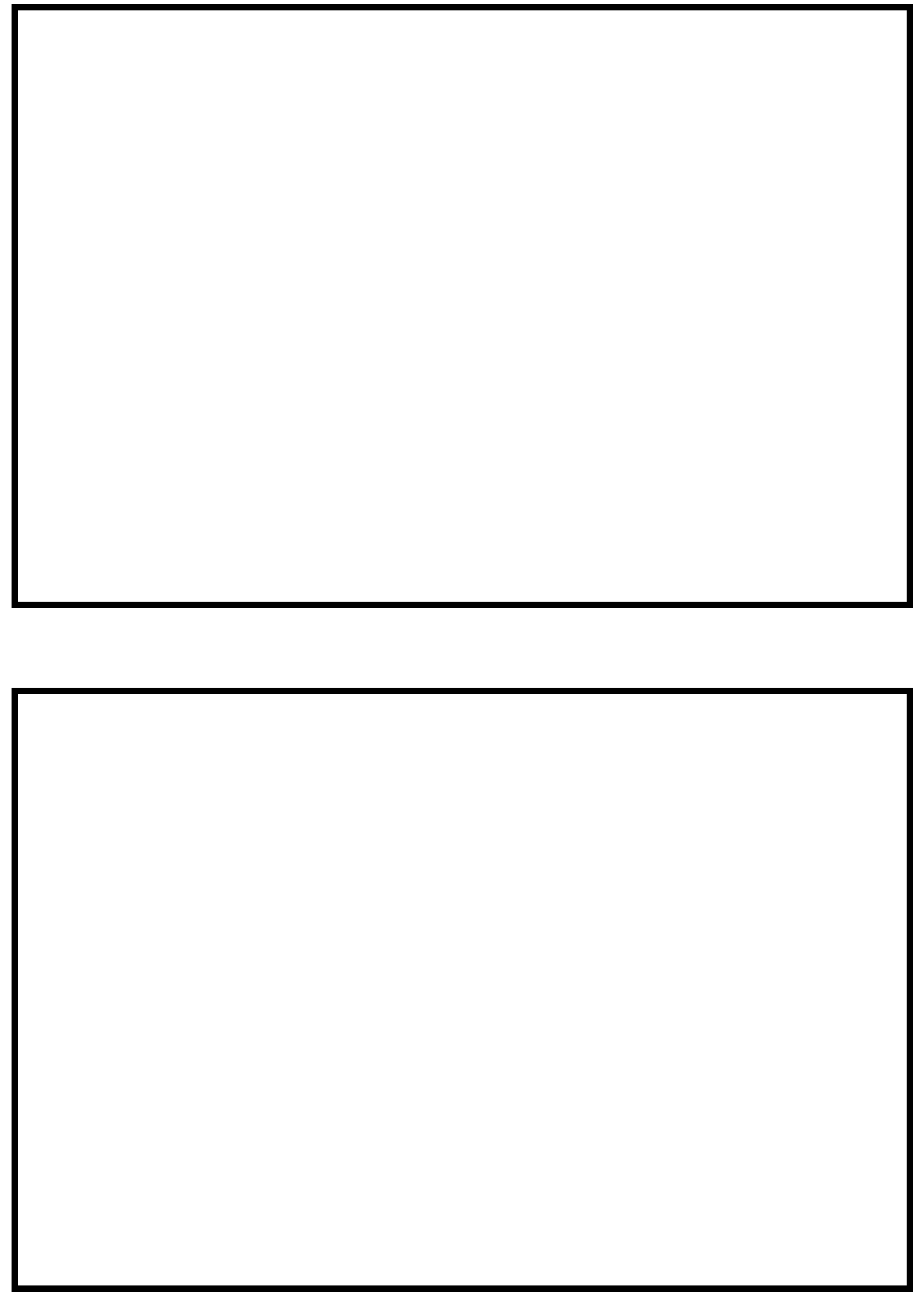


\section{LEVEL II SUMMARY}

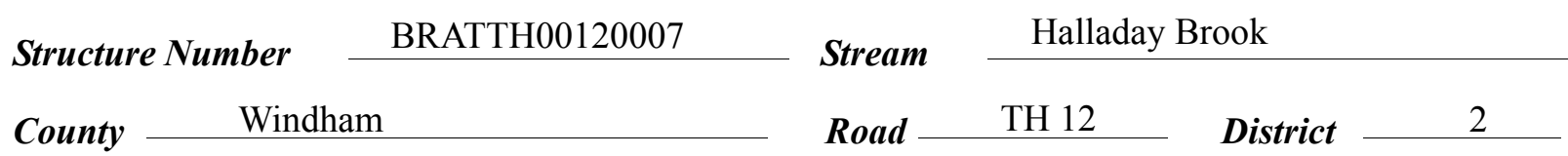

\section{Description of Bridge}

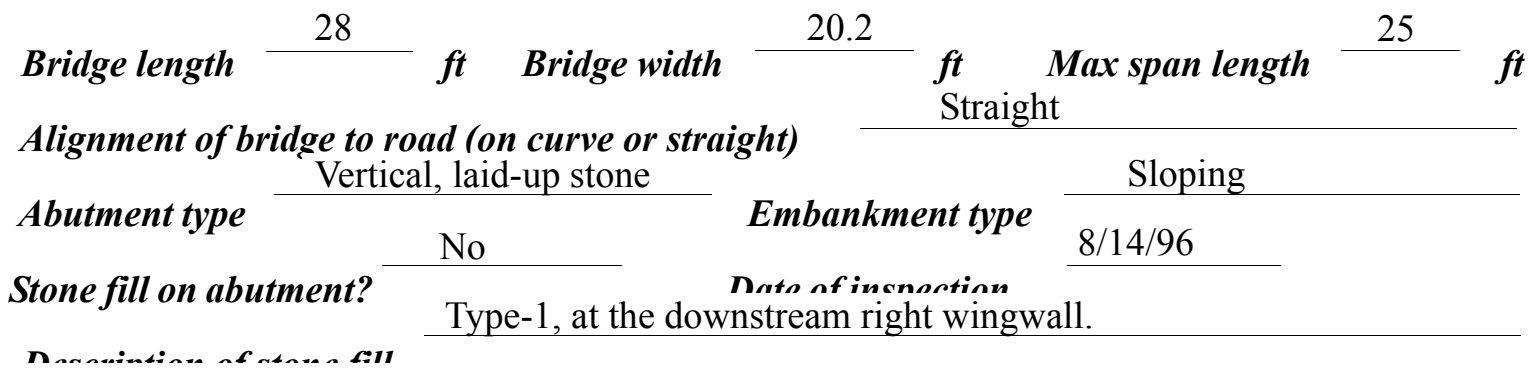

Abutments and wingwalls are laid-up stone except for the downstream right wingwall which is concrete. There is a one foot deep scour hole in front of the right abutment and downstream right wingwall.

$$
\text { Yes }
$$

Is bridge skewed to flood flow according to. Yes 'survey? Angle

There is a moderate channel bend through the bridge. The scour hole has developed in the location where the flow impacts the right abutment and downstream right wingwall.

Debris accumulation on bridge at time of Level I or Level II site visit:

\begin{tabular}{|c|c|c|c|}
\hline & $\begin{array}{c}\text { Date of insnortion } \\
8 / 14 / 96 \\
\end{array}$ & $\begin{array}{l}\text { Percent of almmual } \\
\text { blocked inortzontatly }\end{array}$ & $\begin{array}{l}\text { Percent of } 0 \\
\text { blocked verticatty }\end{array}$ \\
\hline vel I & $8 / 14 / 96$ & 0 & 0 \\
\hline el II & Low. & & \\
\hline
\end{tabular}

Potential for debris

None as of 8/14/96.

Doscriho any, foaturos noar ar at tho hridos that mav, affoct flou, (includo ahsorvation dato) 


\section{Description of the Geomorphic Setting}

General topography The channel is located within a moderate relief valley with a narrow flood plain.

Geomorphic conditions at bridge site: downstream (DS), upstream (US)

Date of inspection $\quad 8 / 14 / 96$

DS left: $\quad$ Moderately sloped overbank

DS right: $\quad$ Narrow flood plain

US left: $\quad$ Mildly sloped overbank

US right: $\quad$ Narrow flood plain

\section{Description of the Channel}

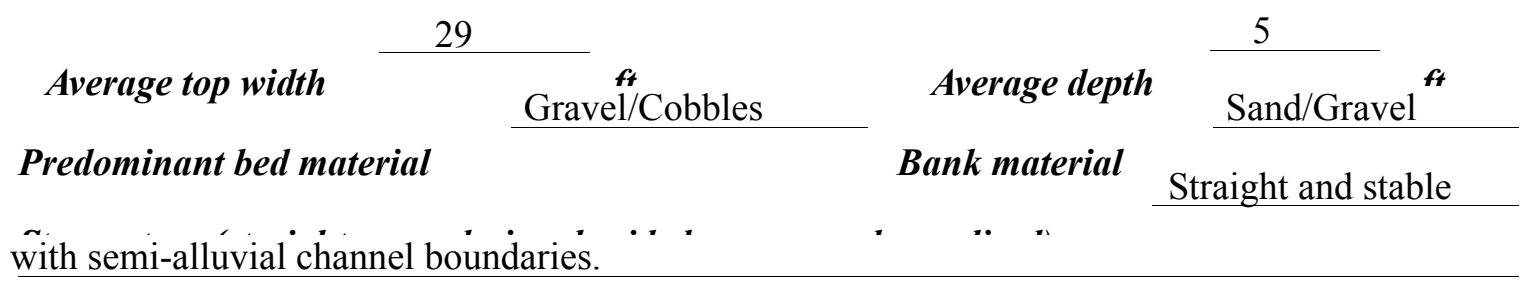

$\begin{array}{ll}\text { Vegetative col } & \text { Grass and brush with lawn on the overbank } \\ \text { DS left: } & \text { Shrubs and brush with lawn on the overbank } \\ \text { DS right: } & \text { Grass and brush with a few trees and lawn on the overbank } \\ \text { US left: } & \text { Trees and brush with lawn and a gravel road on the overbank } \\ \text { US right: } & \text { Yes } \\ \text { Do banks appear stable? - } & \text { yate of observatton. }\end{array}$

The assessment of $8 /$

$14 / 96$ noted bedrock on the right side of the upstream channel. Describe any obstructions in channel and date of observation. 


\title{
Hydrology
}

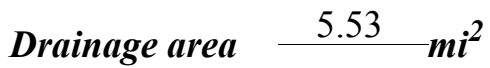

Percentage of drainage area in physiographic provinces: (approximate)

Physiographic province/section New England/New England Upland
Percent of drainage area 100

\begin{abstract}
Is drainage area considered rural or urban? Rural Describe any significant urbanization:
\end{abstract}

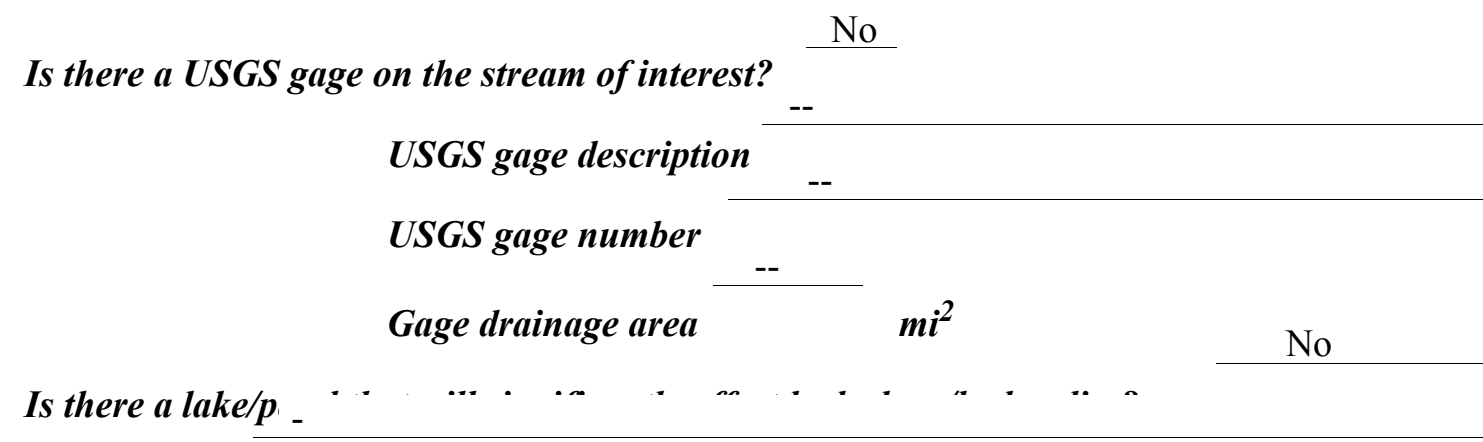

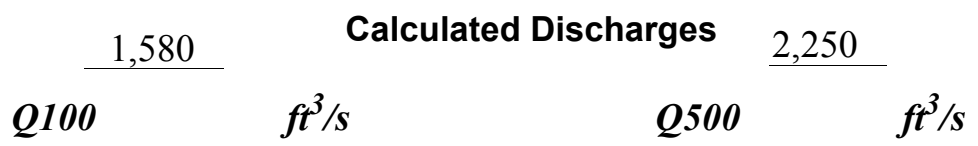

The 100- and 500-year discharges are the median

values from a range defined by flood frequency curves developed by several empirical methods (Benson, 1962; Johnson and Tasker, 1974; FHWA, 1983; Potter, 1957a\&b; Talbot, 1887). 


\section{Description of the Water-Surface Profile Model (WSPRO) Analysis}

Datum for WSPRO analysis (USGS survey, sea level, VTAOT plans)

USGS survey

Datum tie between USGS survey and VTAOT plans

None

Description of reference marks used to determine USGS datum. $\quad$ RM1 is a chiseled X on

top of the downstream right wingwall near the end of the right abutment (elev. $498.86 \mathrm{ft}$,

arbitrary survey datum). RM2 is a chiseled X on top of the concrete bridge deck at the center of

the upstream bridge face (elev. $500.84 \mathrm{ft}$, arbitrary survey datum).

\section{Cross-Sections Used in WSPRO Analysis}

\begin{tabular}{cccl}
\hline ICross-section & $\begin{array}{c}\text { Section } \\
\text { Reference } \\
\text { Distance } \\
\text { (SRD) } \text { in feet }\end{array}$ & $\begin{array}{c}{ }^{2} \text { Cross-section } \\
\text { development }\end{array}$ & \multicolumn{1}{c}{ Comments } \\
\hline EXITX & -26 & 1 & $\begin{array}{l}\text { Exit section } \\
\text { Downstream Full-valley } \\
\text { section (Templated from } \\
\text { EXITX) }\end{array}$ \\
BRIDG & 0 & 2 & $\begin{array}{l}\text { Bridge section } \\
\text { Road Grade section }\end{array}$ \\
RDWAY & 0 & 1 & $\begin{array}{l}\text { Modelled Approach sec- } \\
\text { tion (Templated from } \\
\text { APTEM }\end{array}$ \\
& 19 & 1 & $\begin{array}{l}\text { APTEM) } \\
\text { Approach section as sur- } \\
\text { veyed (Used as a tem- } \\
\text { plate) }\end{array}$ \\
\hline
\end{tabular}

${ }^{1}$ For location of cross-sections see plan-view sketch included with Level I field form, Appendix E.

For more detail on how cross-sections were developed see WSPRO input file. 


\section{Data and Assumptions Used in WSPRO Model}

Hydraulic analyses of the reach were done by use of the Federal Highway Administration's WSPRO step-backwater computer program (Shearman and others, 1986, and Shearman, 1990). The analyses reported herein reflect conditions existing at the site at the time of the study. Furthermore, in the development of the model it was necessary to assume no accumulation of debris or ice at the site. Results of the hydraulic model are presented in the Bridge Hydraulic Summary, appendix B, and figure 7.

Channel roughness factors (Manning's " $n$ ") used in the hydraulic model were estimated using field inspections at each cross section following the general guidelines described by Arcement and Schneider (1989). Final adjustments to the values were made during the modelling of the reach. Channel " $n$ " values for the reach ranged from 0.035 to 0.055 , and overbank " $n$ " values ranged from 0.035 to 0.060 .

For the incipient road-overtopping discharge, normal depth at the exit section (EXITX) was assumed as the starting water surface. This depth was computed by use of the slopeconveyance method outlined in the user's manual for WSPRO (Shearman, 1990). The slope used was $0.0136 \mathrm{ft} / \mathrm{ft}$ which was estimated from surveyed thalweg points downstream of the bridge. For the 100-year and 500-year discharges, critical depth at the exit section (EXITX) was assumed as the starting water surface. Normal depth was computed below critical depth approximately $0.24 \mathrm{ft}$ by use of the slope-conveyance method.

The surveyed approach section (APTEM) was moved along the approach channel slope $(0.0045 \mathrm{ft} / \mathrm{ft})$ to establish the modelled approach section (APPRO), one bridge length upstream of the upstream face as recommended by Shearman and others (1986). This location provides a consistent method for determining scour variables. 


\section{Bridge Hydraulics Summary}

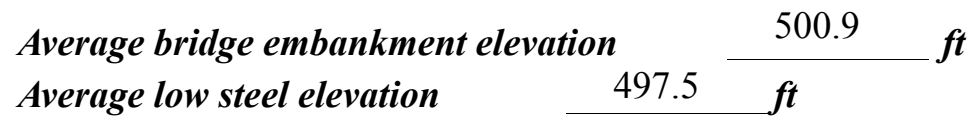

$$
\text { 100-year discharge } \quad 1,580 \quad \mathrm{ft}^{3} / \mathrm{s}
$$

Water-surface elevation in bridge opening $497.6 \quad f t$

Road overtopping? ___ Yes Discharge over road _ $413,3 / s$

Area of flow in bridge opening $\quad 89 \quad \mathrm{ft}^{2}$

Average velocity in bridge opening $13.3 \mathrm{ft} / \mathrm{s}$

$\begin{array}{llll}\text { Maximum WSPRO tube velocity at bridge } & 17.4 \mathrm{ft} / \mathrm{s}\end{array}$

Water-surface elevation at Approach section with bridge 501.8

Water-surface elevation at Approach section without bridge $\quad 498.9$

Amount of backwater caused by bridge $\quad 2.9$ it

500-year discharge $\quad 2,250 \quad \mathrm{ft}^{3} / \mathrm{s}$

Water-surface elevation in bridge opening $497.6 \mathrm{ft}$

Road overtopping? ___ Yes Discharge over road _ $1079, \ldots / s$

Area of flow in bridge opening

Average velocity in bridge opening $\quad 13.4$

Maximum WSPRO tube velocity at bridge 17.5 's

Water-surface elevation at Approach section with bridge 502.4

Water-surface elevation at Approach section without bridge $\quad 501.7$

Amount of backwater caused by bridge $\quad 0.7$.t

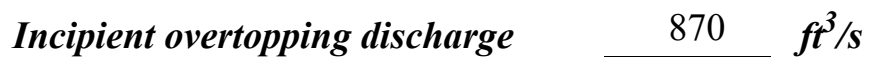

Water-surface elevation in bridge opening $497.6 \quad t$

Area of flow in bridge opening

Average velocity in bridge opening

$89 \quad \boldsymbol{f t}^{2}$

Maximum WSPRO tube velocity at bridge $\quad 12.7 \mathrm{ft} / \mathrm{s}$

Water-surface elevation at Approach section with bridge

Water-surface elevation at Approach section without bridge

Amount of backwater caused by bridge $\quad 3.8$ it

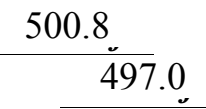




\section{Scour Analysis Summary}

\section{Special Conditions or Assumptions Made in Scour Analysis}

Scour depths were computed using the general guidelines described in Hydraulic Engineering Circular 18 (Richardson and Davis, 1995). Scour depths were calculated assuming an infinite depth of erosive material and a homogeneous particle-size distribution. The results of the scour analyses for the 100- and 500-year discharges are presented in tables 1 and 2 and the scour depths are shown graphically in figure 8.

At this site, the 100-year and 500-year discharges resulted in submerged orifice flow and the incipient road-overtopping discharge resulted in unsubmerged orifice flow. Contraction scour at bridges with orifice flow is best estimated by use of the Chang pressureflow scour equation (oral communication, J. Sterling Jones, October 4, 1996). Thus, contraction scour for these discharges was computed by use of the Chang equation (Richardson and Davis, 1995, p. 145-146). Results of this scour analysis are shown in tables 1 and 2 and figure 8 . The streambed armoring depths computed suggest that armoring will not limit the depth of contraction scour.

For comparison, contraction scour for the discharges resulting in orifice flow was also computed by use of the Laursen clear-water contraction scour equation (Richardson and Davis, 1995, p. 32, equation 20) and the Umbrell pressure-flow equation (Richardson and Davis, 1995, p. 144) and is presented in appendix F. Furthermore, for the incipient roadovertopping discharge, contraction scour was computed by substituting an estimate for the depth of flow at the downstream bridge face in the contraction scour equations. Results with respect to this substitution are provided in appendix F.

Abutment scour at the left abutment was computed by use of the Froehlich equation (Richardson and Davis, 1995, p. 48, equation 28). Variables for the Froehlich equation include the Froude number of the flow approaching the embankments, the length of the embankment blocking flow, and the depth of flow approaching the embankment less any roadway overtopping.

Scour at the right abutment was computed by use of the HIRE equation (Richardson and Davis, 1995, p. 49, equation 29) because the HIRE equation is recommended when the length to depth ratio of the embankment blocking flow exceeds 25 . The variables used by the HIRE abutment-scour equation are defined the same as those defined for the Froehlich abutment-scour equation. 


\section{Scour Results}

\section{0-yr discharge 500-yr discharge}

Contraction scour:

(Scour depths in feet)

Main channel

Live-bed scour

Clear-water scour

Depth to armoring

Left overbank

Right overbank

Local scour:

Abutment scour

Left abutment

2.6

2.8

1.7

$4.6-$

$4.8-$

$4.7-$

Right abutment

Pier scour

Pier 1

Pier 2

Pier 3

\section{Abutments:}

Left abutment

Right abutment

Piers:

Pier 1

Pier 2

overtopping discharge 


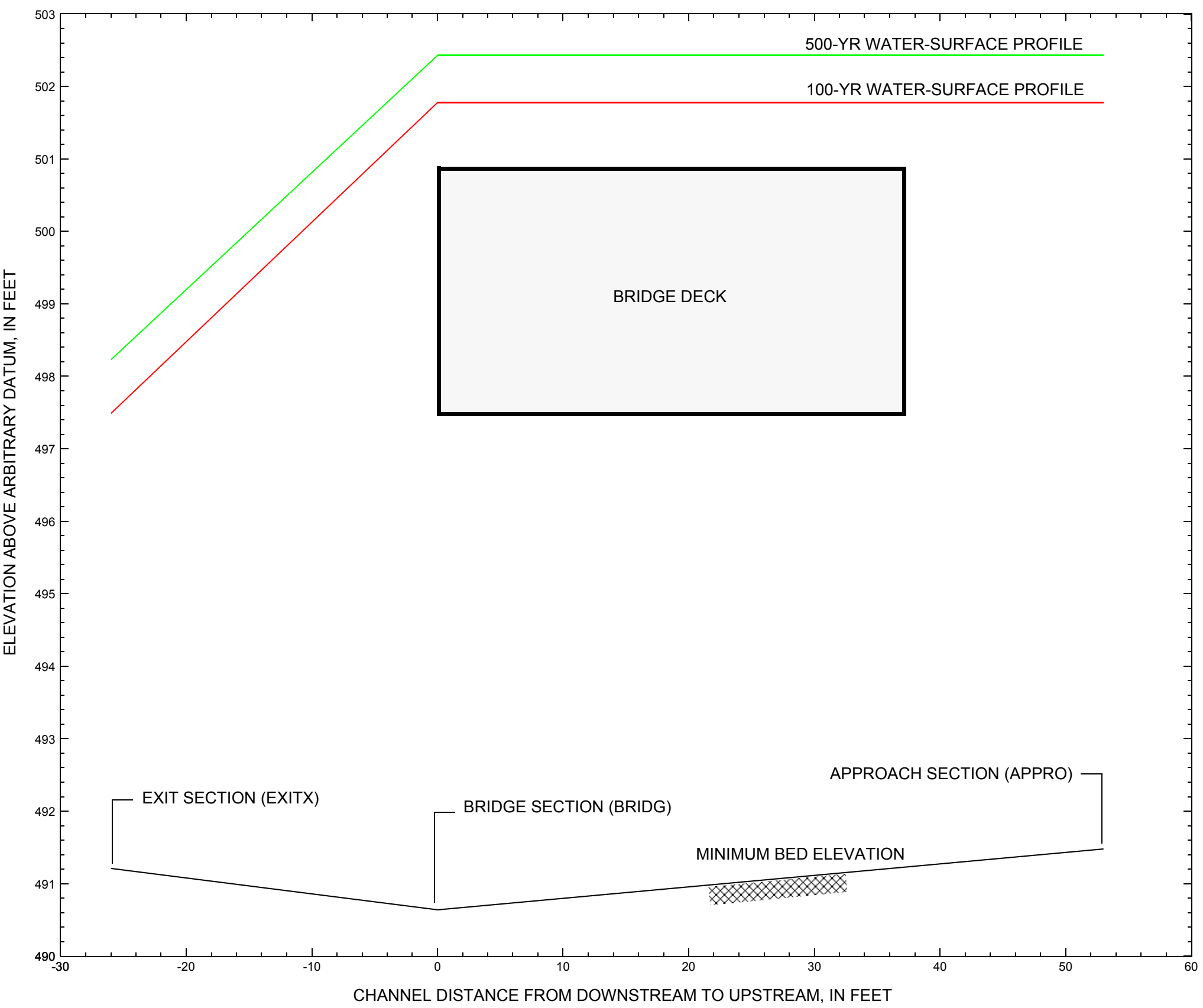

Figure 7. Water-surface profiles for the 100- and 500-yr discharges at structure BRATTH00120007 on Town Highway 12, crossing Halladay Brook, Brattleboro, Vermont. 


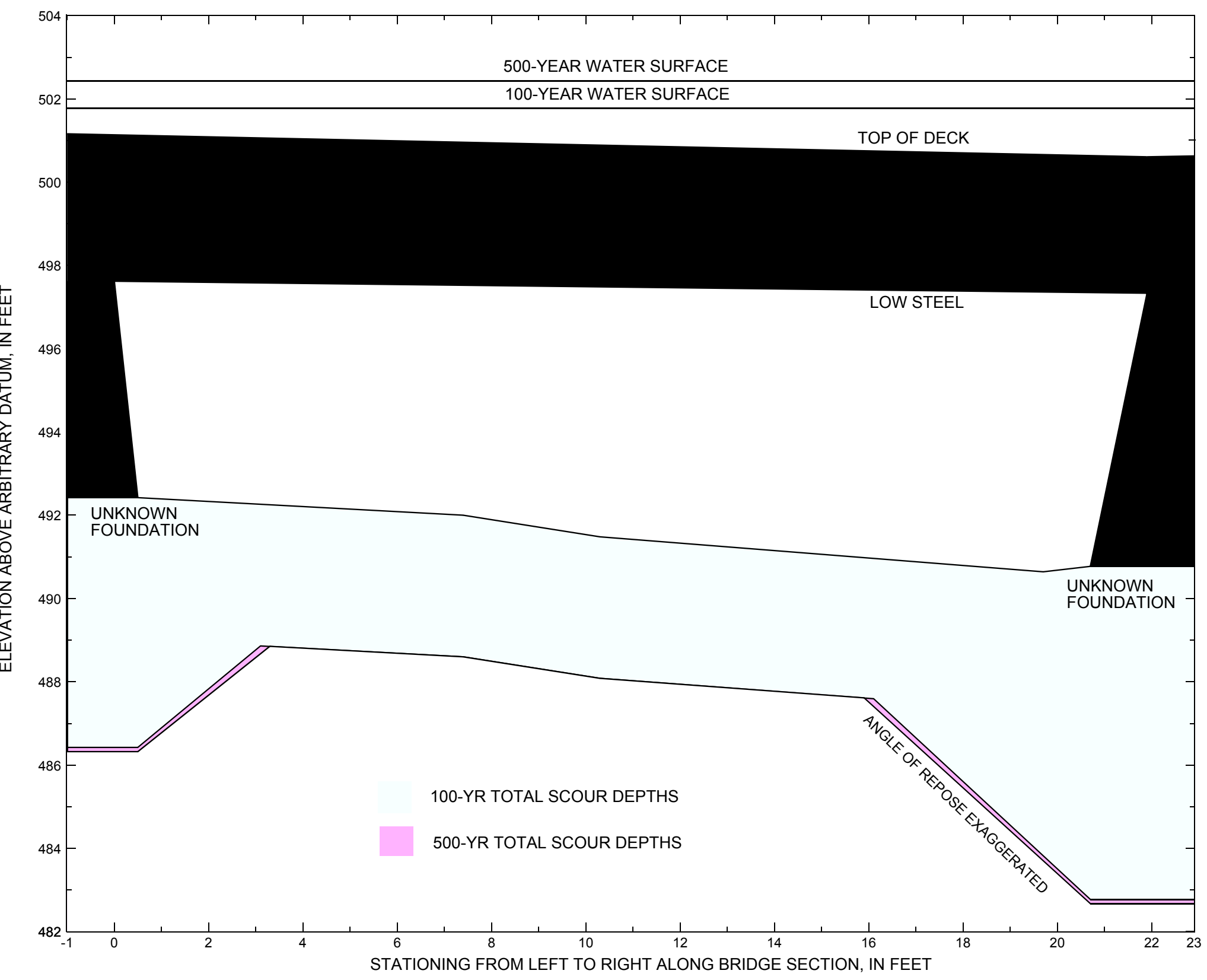

Figure 8. Scour elevations for the 100-yr and 500-yr discharges at structure BRATTH00120007 on Town Highway 12, crossing Halladay Brook, Brattleboro, Vermont. 
Table 1. Remaining footing/pile depth at abutments for the 100-year discharge at structure BRATTH00120007 on Town Highway 12, crossing Halladay Brook, Brattleboro, Vermont.

[VTAOT, Vermont Agency of Transportation; --, no data]

\begin{tabular}{|c|c|c|c|c|c|c|c|c|c|c|c|}
\hline Description & Station $^{1}$ & $\begin{array}{l}\text { VTAOT } \\
\text { minimum } \\
\text { low-chord } \\
\text { elevation } \\
\text { (feet) }\end{array}$ & $\begin{array}{l}\text { Surveyed } \\
\text { minimum } \\
\text { low-chord } \\
\text { elevation }{ }^{2} \\
\text { (feet) }\end{array}$ & $\begin{array}{c}\text { Bottom of } \\
\text { footing/pile } \\
\text { elevation }{ }^{2} \\
\text { (feet) }\end{array}$ & $\begin{array}{c}\text { Channel } \\
\text { elevation at } \\
\text { abutment/ } \\
\text { pier }^{2} \\
\text { (feet) }\end{array}$ & $\begin{array}{l}\text { Contraction } \\
\text { scour depth } \\
\text { (feet) }\end{array}$ & $\begin{array}{l}\text { Abutment } \\
\text { scour } \\
\text { depth } \\
\text { (feet) }\end{array}$ & $\begin{array}{l}\text { Pier } \\
\text { scour } \\
\text { depth } \\
\text { (feet) }\end{array}$ & $\begin{array}{l}\text { Depth of } \\
\text { total scour } \\
\text { (feet) }\end{array}$ & $\begin{array}{c}\text { Elevation of } \\
\text { scour }^{2} \\
\text { (feet) }\end{array}$ & $\begin{array}{c}\text { Remaining } \\
\text { footing/pile } \\
\text { depth } \\
\text { (feet) }\end{array}$ \\
\hline \multicolumn{12}{|c|}{100 -yr. discharge is 1,580 cubic-feet per second } \\
\hline Left abutment & 0.0 & -- & 497.6 & -- & 492.4 & 3.4 & 2.6 & -- & 6.0 & 486.4 & -- \\
\hline Right abutment & 21.9 & -- & 497.3 & -- & 490.8 & 3.4 & 4.6 & -- & 8.0 & 482.8 & -- \\
\hline
\end{tabular}

1.Measured along the face of the most constricting side of the bridge.

2.Arbitrary datum for this study.

Table 2. Remaining footing/pile depth at abutments for the 500-year discharge at structure BRATTH00120007 on Town Highway 12, crossing Halladay Brook, Brattleboro, Vermont.

[VTAOT, Vermont Agency of Transportation; --, no data]

\begin{tabular}{|c|c|c|c|c|c|c|c|c|c|c|c|}
\hline Description & Station $^{1}$ & $\begin{array}{l}\text { VTAOT } \\
\text { minimum } \\
\text { low-chord } \\
\text { elevation } \\
\text { (feet) }\end{array}$ & $\begin{array}{c}\text { Surveyed } \\
\text { minimum } \\
\text { low-chord } \\
\text { elevation } \\
\text { (feet) }\end{array}$ & $\begin{array}{c}\text { Bottom of } \\
\text { footing/pile } \\
\text { elevation } \\
\text { (feet) }\end{array}$ & $\begin{array}{c}\text { Channel } \\
\text { elevation at } \\
\text { abutment/ } \\
\text { pier }^{2} \\
\text { (feet) }\end{array}$ & $\begin{array}{l}\text { Contraction } \\
\text { scour depth } \\
\text { (feet) }\end{array}$ & $\begin{array}{c}\text { Abutment } \\
\text { scour } \\
\text { depth } \\
\text { (feet) }\end{array}$ & $\begin{array}{l}\text { Pier } \\
\text { scour } \\
\text { depth } \\
\text { (feet) }\end{array}$ & $\begin{array}{l}\text { Depth of } \\
\text { total scour } \\
\text { (feet) }\end{array}$ & $\begin{array}{c}\text { Elevation of } \\
\text { scour }^{2} \\
\text { (feet) }\end{array}$ & $\begin{array}{c}\text { Remaining } \\
\text { footing/pile } \\
\text { depth } \\
\text { (feet) }\end{array}$ \\
\hline \multicolumn{12}{|c|}{500 -yr. discharge is 2,250 cubic-feet per second } \\
\hline Left abutment & 0.0 & -- & 497.6 & -- & 492.4 & 3.3 & 2.8 & -- & 6.1 & 486.3 & -- \\
\hline Right abutment & 21.9 & -- & 497.3 & -- & 490.8 & 3.3 & 4.8 & -- & 8.1 & 482.7 & -- \\
\hline
\end{tabular}

1.Measured along the face of the most constricting side of the bridge.

2.Arbitrary datum for this study. 


\section{SELECTED REFERENCES}

Arcement, G.J., Jr., and Schneider, V.R., 1989, Guide for selecting Manning's roughness coefficients for natural channels and flood plains: U.S. Geological Survey Water-Supply Paper 2339, 38 p.

Barnes, H.H., Jr., 1967, Roughness characteristics of natural channels: U.S. Geological Survey Water-Supply Paper 1849,213 p.

Benson, M. A., 1962, Factors Influencing the Occurrence of Floods in a Humid Region of Diverse Terrain: U.S. Geological Survey Water-Supply Paper 1580-B, $64 \mathrm{p}$.

Brown, S.A. and Clyde, E.S., 1989, Design of riprap revetment: Federal Highway Administration Hydraulic Engineering Circular No. 11, Publication FHWA-IP-89-016, 156 p.

Federal Highway Administration, 1983, Runoff estimates for small watersheds and development of sound design: Federal Highway Administration Report FHWA-RD-77-158.

Federal Highway Administration, 1993, Stream Stability and Scour at Highway Bridges: Participant Workbook: Federal Highway Administration Report FHWA-HI-91-011.

Federal Emergency Management Agency, 1985, Flood Insurance Study, Town of Brattleboro, Windham County, Vermont: Washington, D.C., December 4, 1985.

Froehlich, D.C., 1989, Local scour at bridge abutments in Ports, M.A., ed., Hydraulic Engineering--Proceedings of the 1989 National Conference on Hydraulic Engineering: New York, American Society of Civil Engineers, p. 13-18.

Hayes, D.C.,1993, Site selection and collection of bridge-scour data in Delaware, Maryland, and Virginia: U.S. Geological Survey WaterResources Investigation Report 93-4017, 23 p.

Interagency Advisory Committee on Water Data, 1982, Guidelines for determining flood flow frequency: U.S. Geological Survey, Bulletin 17B of the Hydrology Subcommittee, $190 \mathrm{p}$.

Johnson, C.G. and Tasker, G.D.,1974, Progress report on flood magnitude and frequency of Vermont streams: U.S. Geological Survey Open-File Report 74-130, $37 \mathrm{p}$.

Lagasse, P.F., Schall, J.D., Johnson, F., Richardson, E.V., Chang, F., 1995, Stream Stability at Highway Structures: Federal Highway Administration Hydraulic Engineering Circular No. 20, Publication FHWA-IP-90-014, 144 p.

Laursen, E.M., 1960, Scour at bridge crossings: Journal of the Hydraulics Division, American Society of Civil Engineers, v. 86, no. HY2, p. 3953.

Potter, W. D., 1957a, Peak rates of runoff in the Adirondack, White Mountains, and Maine woods area, Bureau of Public Roads

Potter, W. D., 1957b, Peak rates of runoff in the New England Hill and Lowland area, Bureau of Public Roads

Richardson, E.V. and Davis, S.R., 1995, Evaluating scour at bridges: Federal Highway Administration Hydraulic Engineering Circular No. 18, Publication FHWA-IP-90-017, 204 p.

Richardson, E.V., Simons, D.B., and Julien, P.Y., 1990, Highways in the river environment: Federal Highway Administration Publication FHWA-HI-90-016.

Ritter, D.F., 1984, Process Geomorphology: W.C. Brown Co., Debuque, Iowa, 603 p.

Shearman, J.O., 1990, User's manual for WSPRO--a computer model for water surface profile computations: Federal Highway Administration Publication FHWA-IP-89-027, 187 p.

Shearman, J.O., Kirby, W.H., Schneider, V.R., and Flippo, H.N., 1986, Bridge waterways analysis model; research report: Federal Highway Administration Publication FHWA-RD-86-108, 112 p.

Talbot, A.N., 1887, The determination of water-way for bridges and culverts.

U.S. Geological Survey, 1984, Brattleboro, Vermont-New Hampshire 7.5 x 15 Minute Series quadrangle map: U.S. Geological Survey Topographic Maps, Scale 1:25,000.

U.S. Geological Survey, 1984, Newfane, Vermont-New Hampshire 7.5 x 15 Minute Series quadrangle map: U.S. Geological Survey Topographic Maps, Scale 1:25,000. 


\section{APPENDIX A: \\ WSPRO INPUT FILE}




\section{WSPRO INPUT FILE}

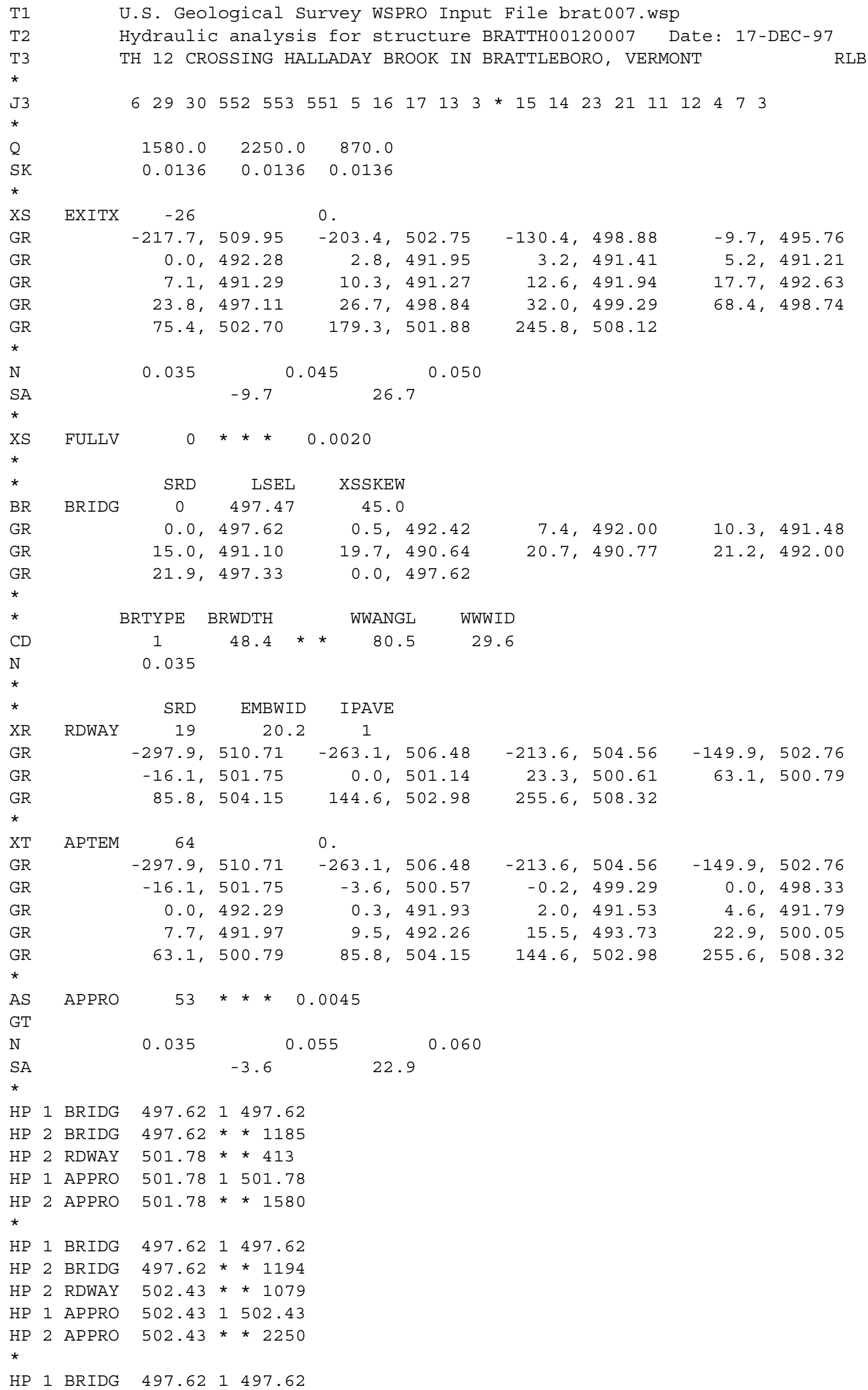




\section{APPENDIX B: \\ WSPRO OUTPUT FILE}




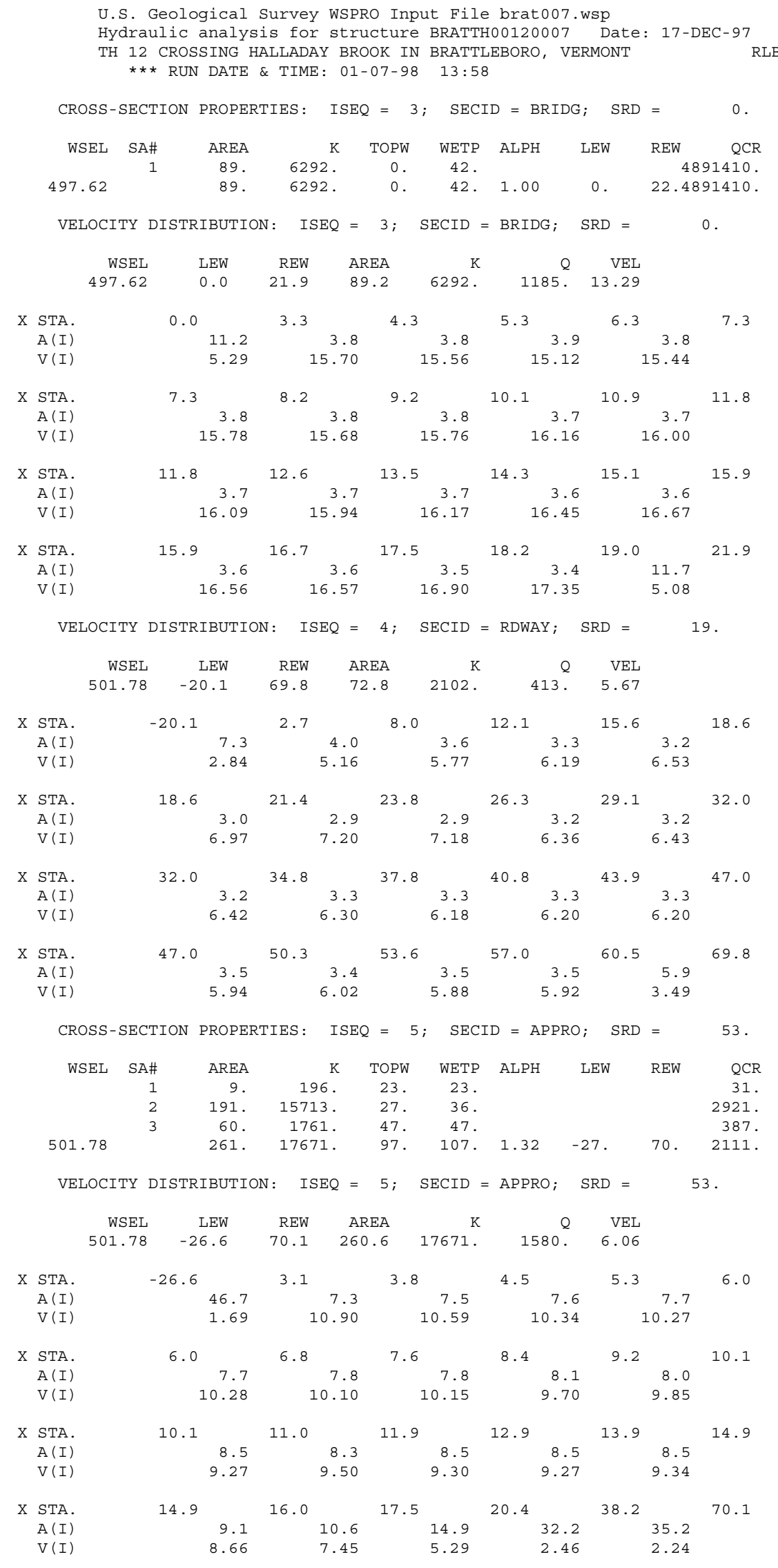


WSPRO OUTPUT FILE (continued)

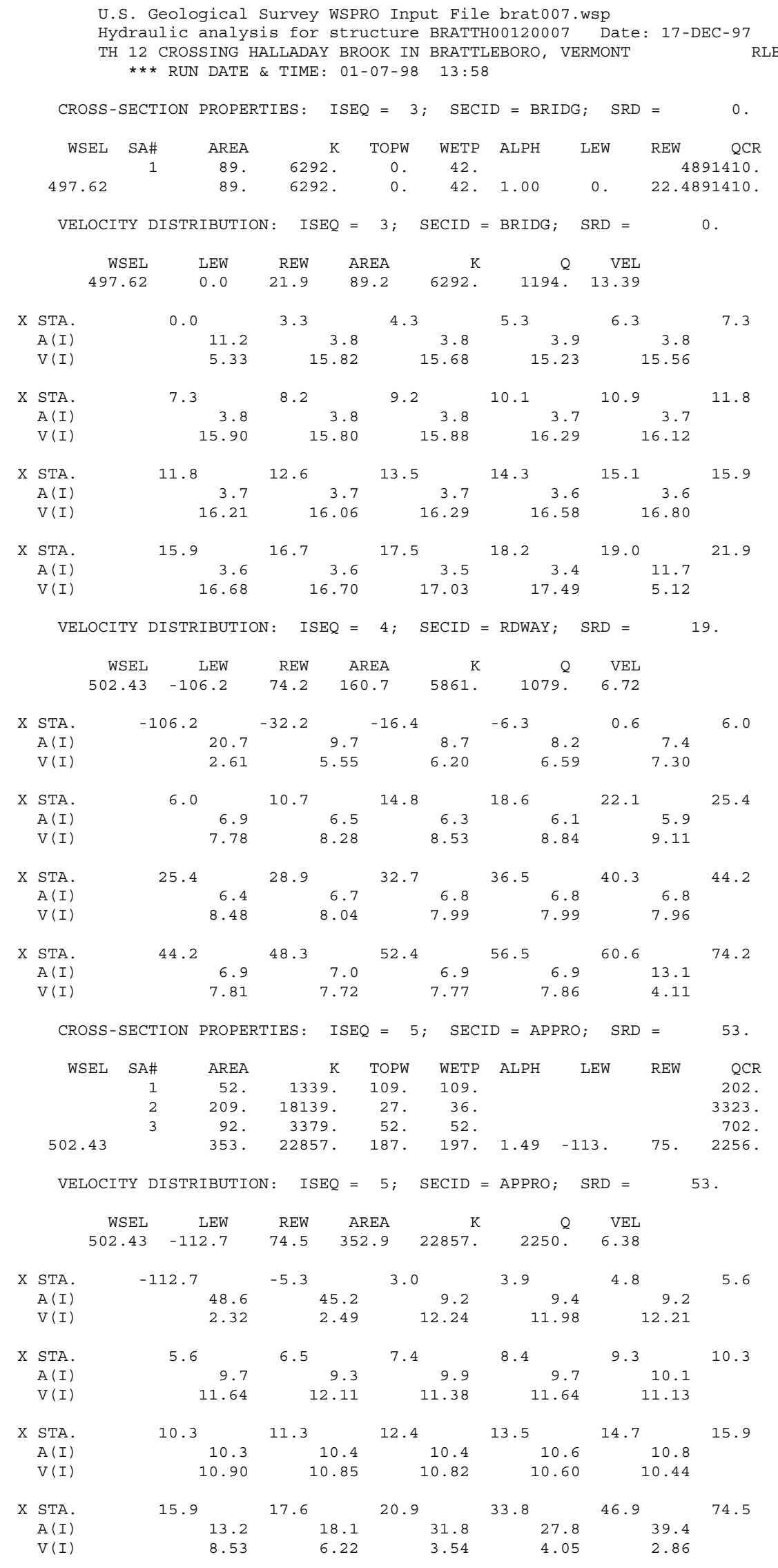


WSPRO OUTPUT FILE (continued)

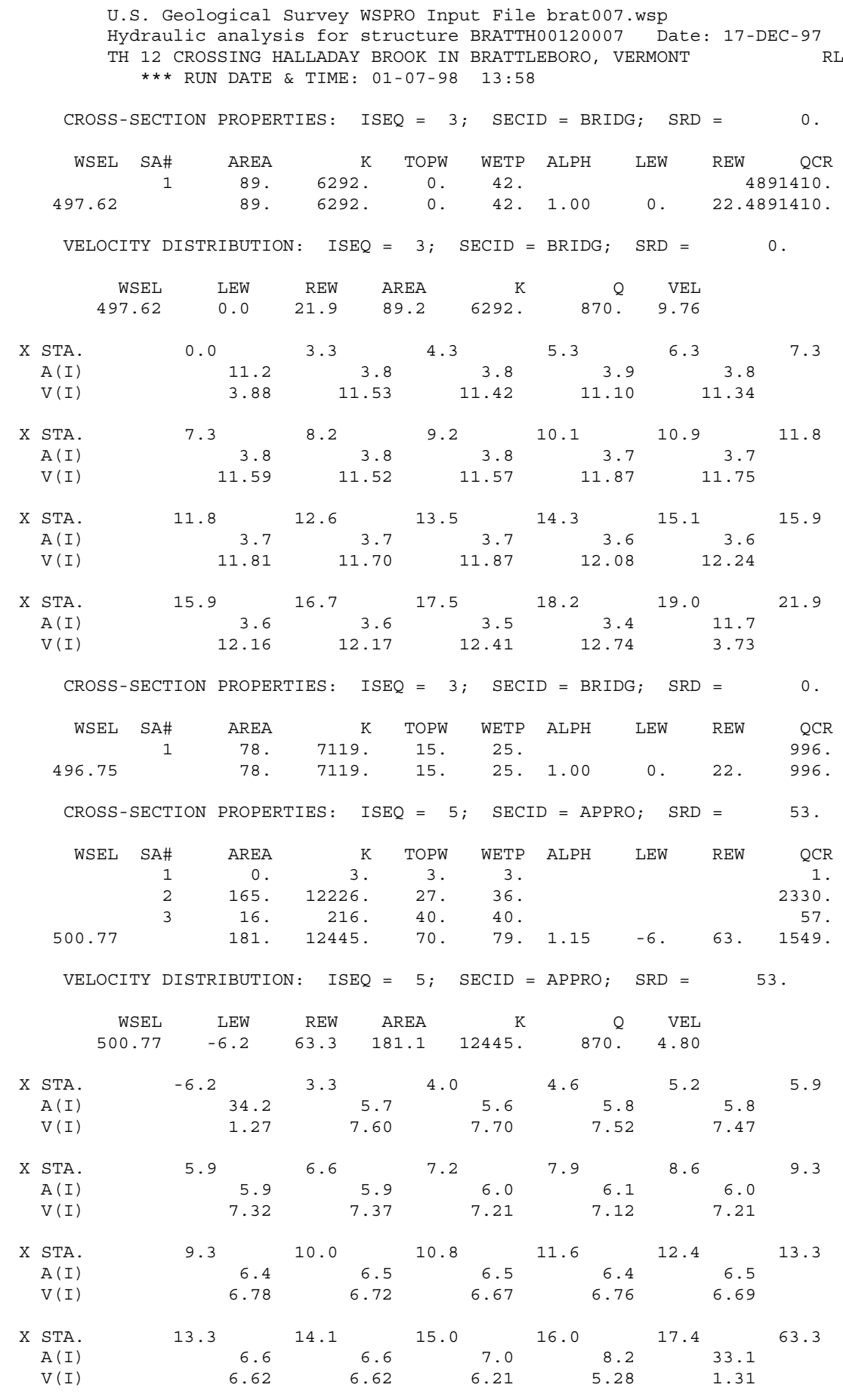


WSPRO OUTPUT FILE (continued)

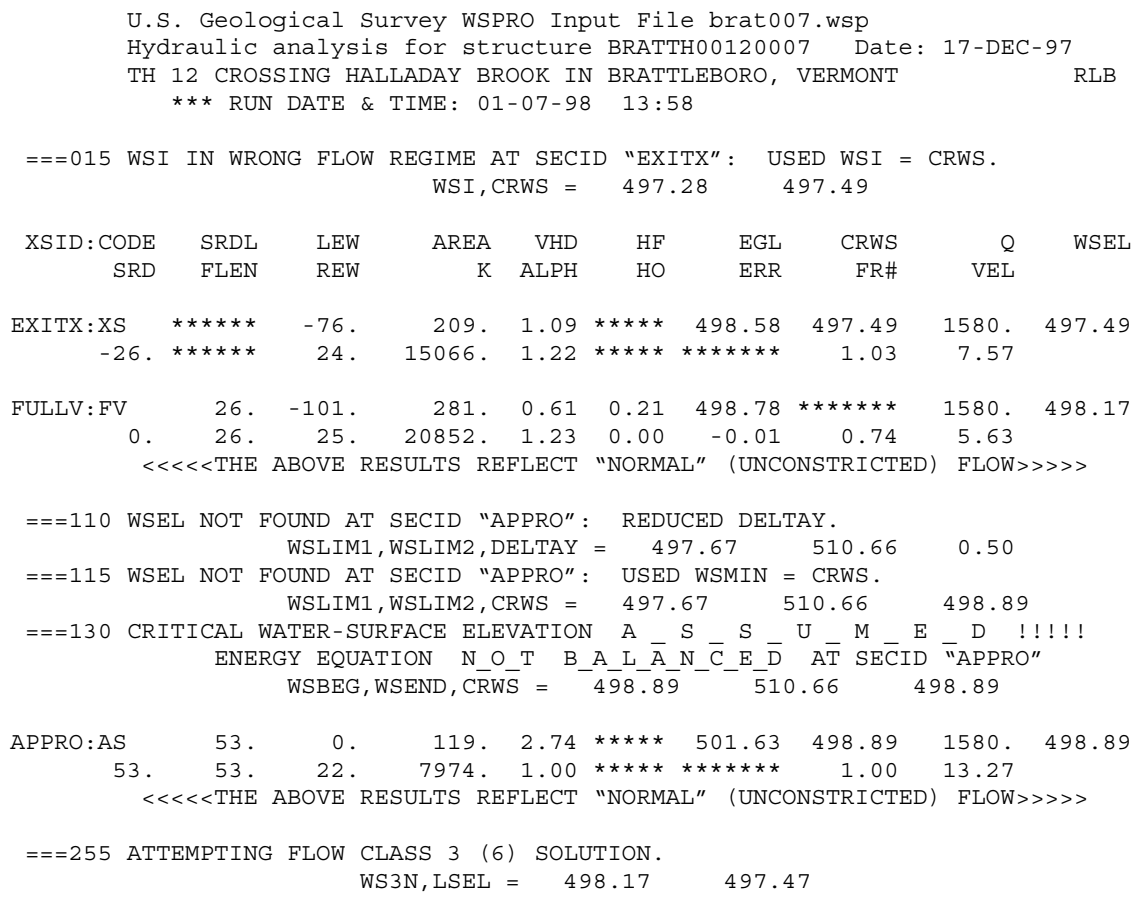

FIRST USER DEFINED TABLE.

\begin{tabular}{|c|c|c|c|c|c|c|c|c|}
\hline XSID : CODE & SRD & LEW & REW & 0 & $\mathrm{~K}$ & AREA & VEL & WSEL \\
\hline EXITX:XS & -26 & -76 & 24 . & 1580. & 15066 . & 209. & 7.57 & 497.49 \\
\hline FULLV : FV & 0. & -101. & 25 . & 1580. & 20852 . & 281. & 5.63 & 498.17 \\
\hline BRIDG : BR & 0. & 0 . & 22 . & 1185. & 6292. & 89. & 13.29 & 497.62 \\
\hline RDWAY : RG & 19. * & $\star \star \star \star \star \star *$ & 88. & 413. & 0. & $* \star * \star *$ & 1.00 & 501.78 \\
\hline APPRO: AS & 53 & -27. & 70. & 1580. & 17671. & 261. & 6.06 & 501.78 \\
\hline XSID : CODE & XLKQ & XRKQ & & & & & & \\
\hline
\end{tabular}

SECOND USER DEFINED TABLE.

$\begin{array}{lrrrrrrrrr}\text { XSID : CODE } & \text { CRWS } & \text { FR\# } & \text { YMIN } & \text { YMAX } & \text { HF } & \text { HO } & \text { VHD } & \text { EGL } & \text { WSEL } \\ \text { EXITX: }: \text { S } & 497.49 & 1.03 & 491.21 & 509.95 * * * * * * * * * * & 1.09 & 498.58 & 497.49 \\ \text { FULLV }: \text { FV } & * * * * * * * * & 0.74 & 491.26 & 510.00 & 0.21 & 0.00 & 0.61 & 498.78 & 498.17 \\ \text { BRIDG : BR } & 497.33 & 1.16 & 490.64 & 497.62 * * * * * * * * * * * & 2.75 & 500.37 & 497.62 \\ \text { RDWAY : RG } & * * * * * * * * * * * * * * * * & 500.61 & 510.71 & 0.26 * * * * * * & 0.76 & 502.27 & 501.78 \\ \text { APPRO : AS } & 498.89 & 0.75 & 491.48 & 510.66 & 0.08 & 0.00 & 0.76 & 502.54 & 501.78\end{array}$


WSPRO OUTPUT FILE (continued)

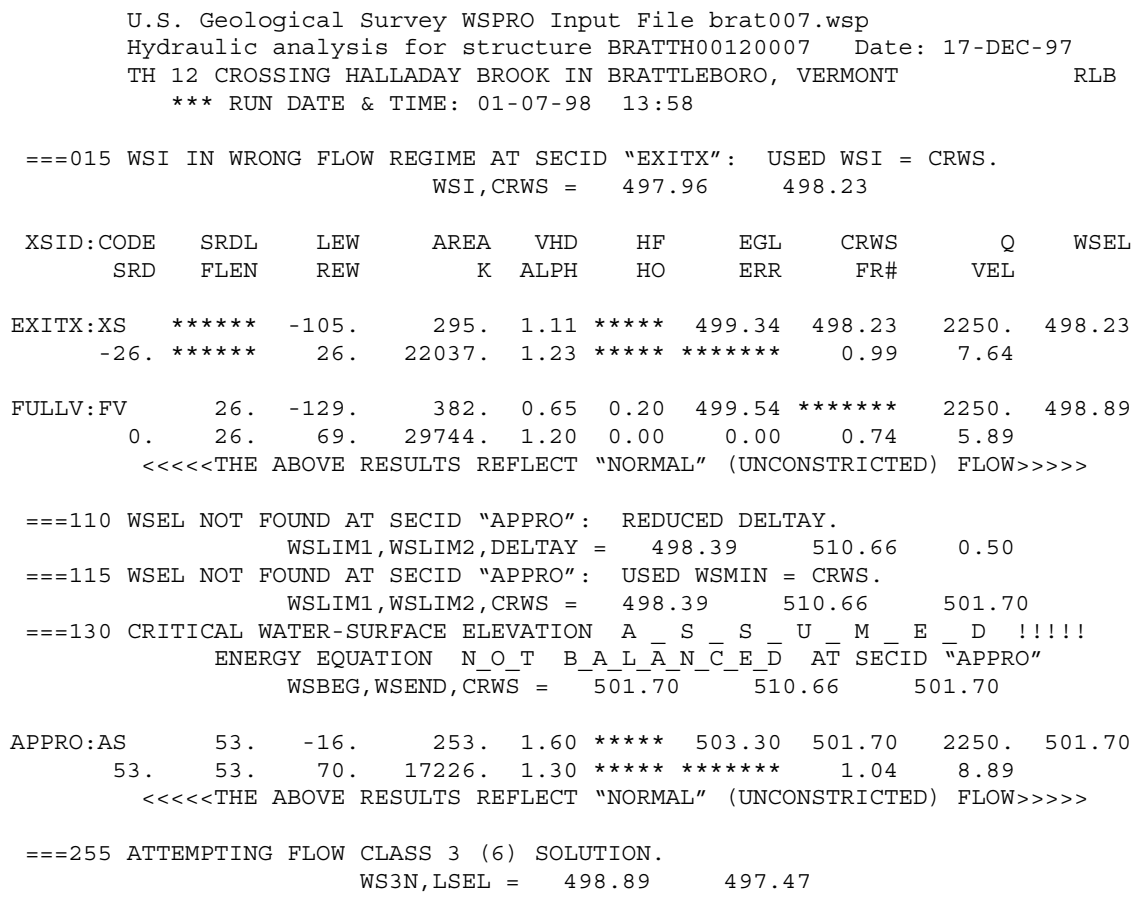

FIRST USER DEFINED TABLE.

\begin{tabular}{|c|c|c|c|c|c|c|c|c|}
\hline XSID : CODE & SRD & LEW & REW & Q & $\mathrm{K}$ & AREA & VEL & WSEL \\
\hline EXITX:XS & -26 & -105 & 26. & 2250 . & 22037 . & 295. & 7.64 & 498.23 \\
\hline FULLV : FV & 0 . & -129 & 69. & 2250 . & 29744 & 382 . & 5.89 & 498.89 \\
\hline BRIDG : BR & 0 . & 0 . & 22. & 1194. & 6292. & 89. & 13.39 & 497.62 \\
\hline RDWAY : RG & 19. * & $* \star \star \star * * *$ & 462 . & 1079. & $\star * \star * \star \star * * *$ & $\star \star \star \star \star *$ & 1.00 & 502.43 \\
\hline APPRO: AS & 53 & -113. & 75. & 2250 . & 22847 & 353. & 6.38 & 502.43 \\
\hline XSID : CODE & XLKQ & XRKQ & & & & & & \\
\hline
\end{tabular}

SECOND USER DEFINED TABLE.

\begin{tabular}{|c|c|c|c|c|c|c|c|c|c|}
\hline $\mathrm{E}$ & CRWS & FR\# & YMIN & YMAX & $\mathrm{HF}$ & $\mathrm{HO}$ & VHD & EGL & \\
\hline EXITX:XS & 498.23 & 99 & 91.21 & 09.95 * & & & 1.11 & 99.34 & \\
\hline UL & 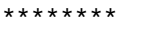 & & 1.26 & 0.00 & 0.20 & 0.00 & .65 & 4 & \\
\hline & .33 & 17 & 64 & 97.62 * & $* \star \star \star * *$ & 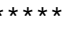 & .79 & & \\
\hline & $k * *$ & * & & & 0 & $\star \star \star \star \star \star *$ & .94 & & \\
\hline PPRO : AS & 501.70 & 1.00 & 491.48 & 510.66 & 0.13 & 0.00 & 0.94 & 503.37 & 02 \\
\hline
\end{tabular}


WSPRO OUTPUT FILE (continued)

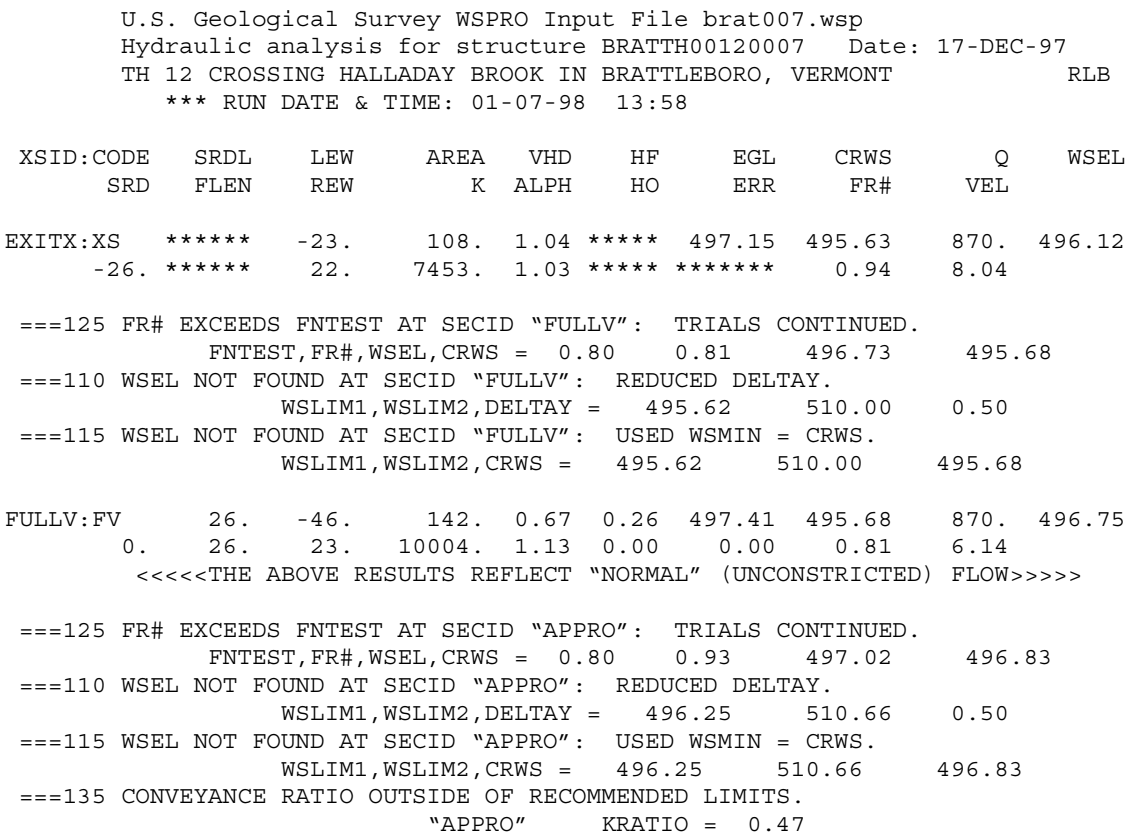




\section{APPENDIX C:}

\section{BED-MATERIAL PARTICLE-SIZE DISTRIBUTION}




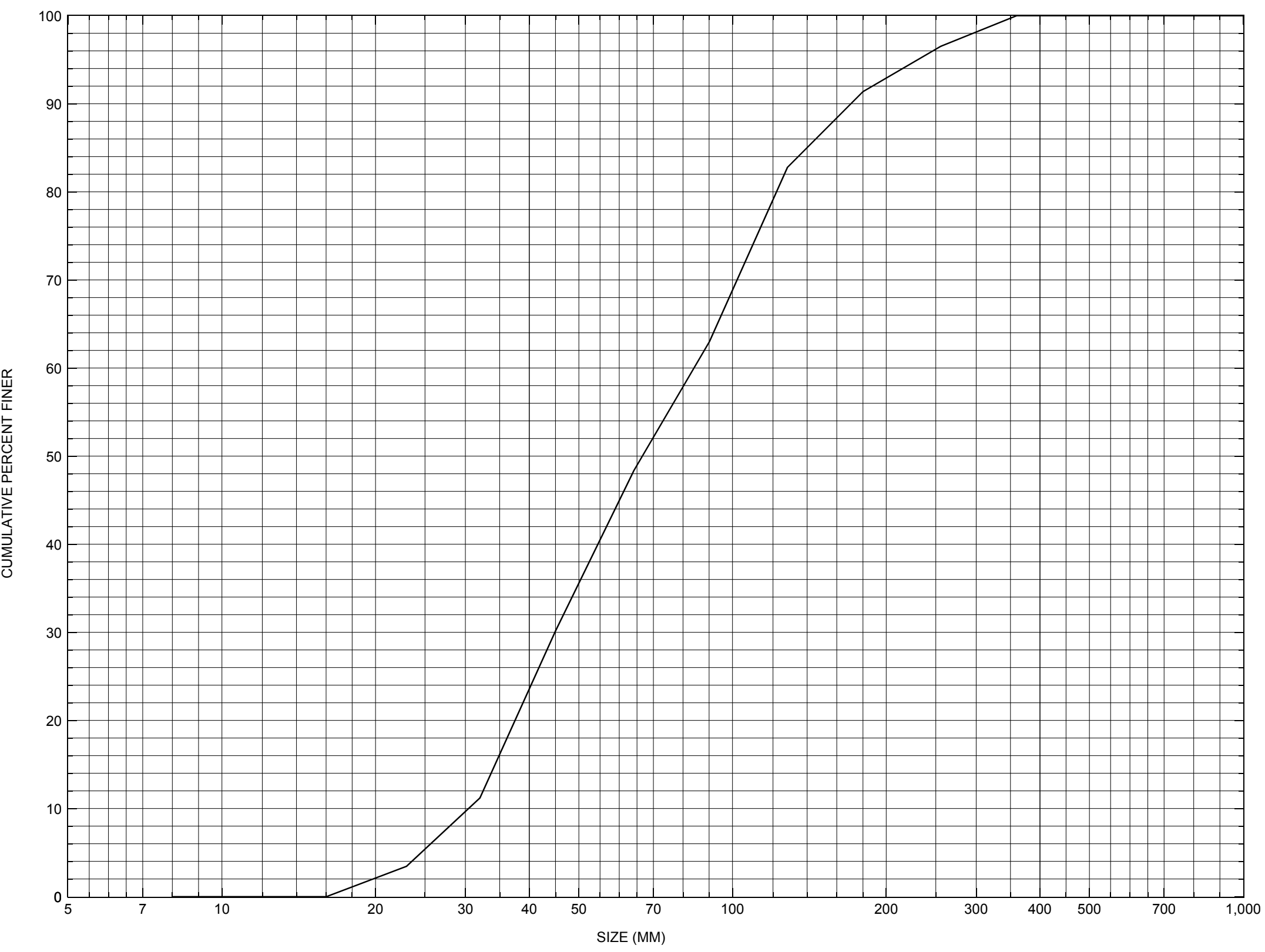

Appendix C. Bed material particle-size distribution for a pebble count in the channel approach of structure BRATTH00120007, in Brattleboro, Vermont. 


\section{APPENDIX D: \\ HISTORICAL DATA FORM}




\section{Structure Number BRATTH00120007}

\section{General Location Descriptive}

Data collected by (First Initial, Full last name) $\mathbf{M}$. IVANOFF

Date $(M M / D D / Y Y) \_\mathbf{0 4} / \underline{05} / \underline{95}$

Highway District Number (I - 2; nn) $\mathbf{0 2}$

Town (FIPS place code; I - 4; nnnnn) $\mathbf{0 7 9 0 0}$

Waterway ( $($ - 6) HALLADAY BROOK

Route Number TH012

Topographic Map Brattleboro

Latitude (I - 16; nnnn.n) $\mathbf{4 2 5 2 2}$
County (FIPS county code; I - 3; nnn)

Mile marker (I - 11; nnn.nnn) $\mathbf{0 0 0 0 0 0}$

Road Name (I - 7): -

Vicinity (I - 9) 0.2 MI TO JCT W VT9

Hydrologic Unit Code: $\mathbf{0 1 0 8 0 1 0 4}$

Longitude (i - 17; nnnnn.n) $\mathbf{7 2 3 7 3}$

\section{Select Federal Inventory Codes}

FHWA Structure Number (I - 8) $\mathbf{1 0 1 3 0 2 0 0 0 7 1 3 0 2}$

Maintenance responsibility $(I-21 ; n n) \quad \mathbf{0 3} \quad$ Maximum span length $(I-48 ; n n n n) \underline{\mathbf{0 0 2 5}}$

Year built (I - 27; YYYY) 1920

Structure length (I - 49; nnnnnn) $\underline{\mathbf{0 0 0 0 2 8}}$

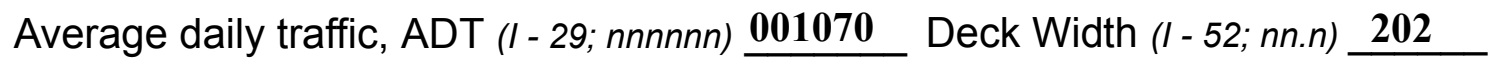

Year of ADT (I - 30; YY) $\underline{\mathbf{9 1}}$

Channel \& Protection $(I-61 ; n) \underline{6}$

Opening skew to Roadway $(I-34 ; n n) \quad \mathbf{4 5}$

Waterway adequacy $(I-71 ; n)$

Operational status $(I-41 ; X)$ A

Underwater Inspection Frequency $(I-92 B ; X Y Y) \_\mathbf{N}$

Structure type (I - 43; nnn) 101

Year Reconstructed (I - 106) $\mathbf{0 0 0 0}$

Approach span structure type (I - 44; nnn) $\mathbf{0 0 0}$ Clear span (nnn.n ft)

Number of spans (I - 45; nnn) $\mathbf{0 0 1}$

Vertical clearance from streambed (nnn.n ft) $\underline{\mathbf{0 0 5 . 2}}$

Number of approach spans (I - 46; nnnn) $\mathbf{0 0 0 0}$ Waterway of full opening (nnn.n $\left.\mathrm{ft}^{2}\right)$

Comments:

The structural inspection report of $08 / 22 / 94$ indicates the structure is a concrete slab bridge with an asphalt road surface. Both abutments are constructed of "laid-up" stone. They have some random small voids and slight bulges, but overall they reportedly are quite stable. The waterway makes a sharp turn into the structure. The upstream right wingwall has a corrugated, galvanized 12 inch diameter drain pipe sticking out of it. The downstream right wingwall is concrete. The streambed consists of stone and gravel and there is a shallow gravel point bar deposited along the left abutment. Stone fill consists of natural streambed material. 


\section{Bridge Hydrologic Data}

Is there hydrologic data available? $\underline{\mathbf{N}}$ if No, type ctrl-n $h \quad$ VTAOT Drainage area $\left(m i^{2}\right)$ : -

Terrain character:

Stream character \& type: -

Streambed material:

Discharge Data (cfs):

$$
\begin{aligned}
& Q_{2.33}- \\
& Q_{50}-
\end{aligned}
$$

Record flood date $(M M / D D / Y Y)$ :

Estimated Discharge (cfs): Ice conditions (Heavy, Moderate, Light) : -

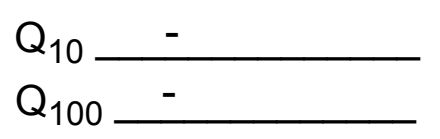

$$
\begin{aligned}
& Q_{25}- \\
& Q_{500}-
\end{aligned}
$$

Water surface elevation $(f t):-$

The stage increases to maximum highwater elevation (Rapidly, Not rapidly):

The stream response is (Flashy, Not flashy):

Describe any significant site conditions upstream or downstream that may influence the stream's stage: -

Watershed storage area (in percent): _ _ \%

The watershed storage area is: - (1-mainly at the headwaters; 2- uniformly distributed; 3-immediatly upstream oi the site)

Water Surface Elevation Estimates for Existing Structure:

\begin{tabular}{|l|l|l|l|l|l|}
\hline Peak discharge frequency & $Q_{2.33}$ & $Q_{10}$ & $Q_{25}$ & $Q_{50}$ & $Q_{100}$ \\
Water surface elevation (ft)) & - & - & - & - & - \\
Velocity (ft/sec) & - & - & - & - & - \\
\hline
\end{tabular}

Long term stream bed changes: -

Is the roadway overtopped below the $\mathrm{Q}_{100}$ ? (Yes, No, Unknown): $\mathbf{U}$ Frequency: Relief Elevation (ft): Discharge over roadway at $Q_{100}\left(f^{3} / \mathrm{sec}\right)$ :

Are there other structures nearby? (Yes, No, Unknown): $\underline{\mathbf{U}}$ Upstream distance (miles): Town: If No or Unknown, type ctrl-n os Highway No. : Structure No. : Year Built:

Clear span (ft): Clear Height $(f t)$ : Full Waterway $\left(f^{2}\right)$ : 
Downstream distance (miles): Town: Year Built:

Highway No. : Structure No. : Structure Type:

Clear span (ft): Clear Height $(f t)$ : Full Waterway $\left(f^{2}\right)$ : -

Comments:

\section{USGS Watershed Data}

Watershed Hydrographic Data

Drainage area $(D A) \mathbf{5 . 5 3}$

Watershed storage (ST)

Bridge site elevation

Main channel length

531.5

5.8 $10 \%$ channel length elevation $\mathrm{mi}^{2}$ 0 $\%$

Lake/pond/swamp area $\mathrm{mi}^{2}$

Main channel slope (S)
(S) 181.8 $\mathrm{ft}$ $\mathrm{mi}$

\section{Watershed Precipitation Data}

Average site precipitation in Average headwater precipitation in

Maximum 2yr-24hr precipitation event $(124,2)$ in

Average seasonal snowfall (Sn) $\mathrm{ft}$ 


\section{Bridge Plan Data}

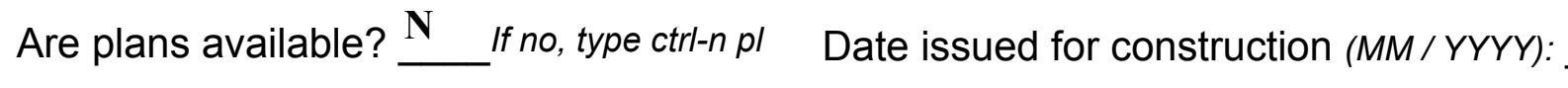

Project Number

Minimum channel bed elevation:

Low superstructure elevation: USLAB DSLAB USRAB DSRAB Benchmark location description:

NO BENCHMARK INFORMATION

Reference Point (MSL, Arbitrary, Other): Datum (NAD27, NAD83, Other):

Foundation Type: 4

If 1 : Footing Thickness

If 2: Pile Type:

If 3: Footing bottom elevation:

Is boring information available? $\mathbf{N}$

Foundation Material Type: $\mathbf{3}$

(1-Spreadfooting; 2-Pile; 3- Gravity; 4-Unknown)

Footing bottom elevation: -

Briefly describe material at foundation bottom elevation or around piles:

NO FOUNDATION MATERIAL INFORMATION 


\section{Cross-sectional Data}

Is cross-sectional data available? Yes If no, type ctrl-n xs

Source (FEMA, VTAOT, Other)? VTAOT

This cross section of the upstream bridge face was attached to a bridge inspection report dated Comments: $8 / 24 / 94$. All measurements are in feet. The data has been converted to the elevation coordinates of this report based on the average low chord elevation. Mid-S. = mid-span.

\begin{tabular}{|l|l|l|l|l|l|l|l|l|l|l|l|}
\hline Station & $\mathbf{0}$ & - & $\mathbf{2 2}$ & - & - & - & - & - & - & - & - \\
\hline Feature & LAB & Mid-S. & RAB & - & - & - & - & - & - & - & - \\
\hline $\begin{array}{l}\text { Low chord } \\
\text { elevation }\end{array}$ & $\mathbf{4 9 7 . 4 8}$ & $\mathbf{4 9 7 . 4 8}$ & $\mathbf{4 9 7 . 4 8}$ & - & - & - & - & - & - & - & - \\
\hline $\begin{array}{l}\text { Bed } \\
\text { elevation }\end{array}$ & $\mathbf{4 9 2 . 4 8}$ & $\mathbf{4 9 1 . 9 8}$ & $\mathbf{4 9 1 . 4 8}$ & - & - & - & - & - & - & - & - \\
\hline $\begin{array}{l}\text { Low chord } \\
\text { to bed }\end{array}$ & $\mathbf{5}$ & $\mathbf{5 . 5}$ & $\mathbf{6}$ & - & - & - & - & - & - & - & - \\
\hline Station & - & - & - & - & - & - & - & - & - & - & - \\
\hline Feature & - & - & - & - & - & - & - & - & - & - & - \\
\hline $\begin{array}{l}\text { Low chord } \\
\text { elevation }\end{array}$ & - & - & - & - & - & - & - & - & - & - & - \\
\hline $\begin{array}{l}\text { Bed } \\
\text { elevation }\end{array}$ & - & - & - & - & - & - & - & - & - & - & - \\
\hline $\begin{array}{l}\text { Low chord } \\
\text { to bed }\end{array}$ & - & - & - & - & - & - & - & - & - & - & - \\
\hline
\end{tabular}

Source (FEMA, VTAOT, Other)?

Comments: -

\begin{tabular}{|l|l|l|l|l|l|l|l|l|l|l|l|}
\hline Station & - & - & - & - & - & - & - & - & - & - & - \\
\hline Feature & - & - & & - & - & - & - & - & - & - & - \\
\hline $\begin{array}{l}\text { Low chord } \\
\text { elevation }\end{array}$ & - & - & & - & - & - & - & - & - & - & - \\
\hline $\begin{array}{l}\text { Bed } \\
\text { elevation }\end{array}$ & - & - & - & - & - & - & - & - & - & - & - \\
\hline $\begin{array}{l}\text { Low chord } \\
\text { to bed }\end{array}$ & - & - & - & - & - & - & - & - & - & - & - \\
\hline Station & - & - & - & - & - & - & - & - & - & - & - \\
\hline Feature & - & - & - & - & - & - & - & - & - & - & - \\
\hline $\begin{array}{l}\text { Low chord } \\
\text { elevation }\end{array}$ & - & - & - & - & - & - & - & - & - & - & - \\
\hline $\begin{array}{l}\text { Bed } \\
\text { elevation }\end{array}$ & - & - & - & - & - & - & - & - & - & - & - \\
\hline $\begin{array}{l}\text { Low chord } \\
\text { to bed }\end{array}$ & - & - & - & - & - & - & - & - & - & - & - \\
\hline
\end{tabular}




\section{APPENDIX E: \\ LEVEL I DATA FORM}


U. S. Geological Survey

Bridge Field Data Collection and Processing Form

Qa/Qc Check by: $\underline{\mathbf{R B}}$ Date: $01 / 23 / 97$

\section{Structure Number}

BRATTH00120007

Computerized by: $\underline{\mathbf{R B}}$ Date: $\mathbf{0 5 / 1 5 / 9 7}$

Reviewd by: $\quad$ RB Date: $\underline{01 / 15 / 98}$

\section{A. General Location Descriptive}

1. Data collected by (First Initial, Full last name) $\mathbf{E}$. BOEHMLER

Date $(M M / D D / Y Y) \mathbf{0 8} / 14 / 1996$

2. Highway District Number 2

County WINDHAM (025)

Waterway ( - 6) HALLADAY BROOK

Route Number TH 12

3. Descriptive comments:

This site is located about 0.2 miles north of the intersection of TH 12 and VT 9.

Mile marker -
Town BRATTLEBORO (07900)

Road Name SUNSET LAKE RD.

Hydrologic Unit Code: $\mathbf{0 1 0 8 0 1 0 4}$

\section{B. Bridge Deck Observations}
4. Surface cover... LBUS 4
RBUS 4
LBDS 4
RBDS 4
Overall 4

(2b us,ds,lb,rb: 1- Urban; 2- Suburban; 3- Row crops; 4- Pasture; 5- Shrub- and brushland; 6- Forest; 7- Wetland)
5. Ambient water surface... US $\underline{2}$
UB 1
DS 1
(1- pool; 2- riffle)

6. Bridge structure type 1 (1- single span; 2- multiple span; 3- single arch; 4- multiple arch; 5-cylindrical culvert; 6- box culvert; or 7- other)
7. Bridge length 28 (feet)
Span length $\underline{\mathbf{2 5}}$
(feet)
Bridge width $\underline{\mathbf{2 0 . 2}}$ (feet)

\section{Road approach to bridge:}
8. LB 2 RB 1
( 0 even, 1- lower, 2- higher)
9. $\mathrm{LB}$
RB 1
(1- Paved, 2- Not paved)

10. Embankment slope (run / rise in feet / foot):

US left

US right

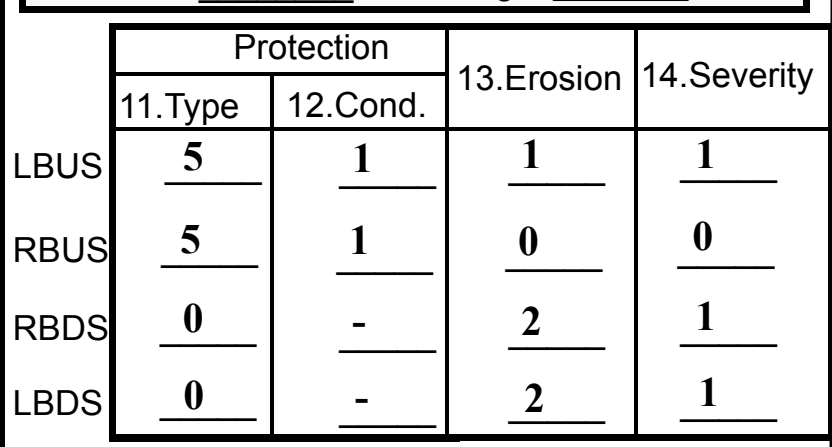

Bank protection types: 0 - none; 1- $<12$ inches;

2- < 36 inches; 3- < 48 inches;

4- $<60$ inches; 5- wall / artificial levee

Bank protection conditions: 1- good; 2- slumped;

3- eroded; 4- failed

Erosion: 0 - none; 1- channel erosion; 2-

road wash; 3- both; 4- other

Erosion Severity: 0 - none; 1- slight; 2- moderate;

\section{Channel approach to bridge (BF):}

15. Angle of approach: $\mathbf{1 0}$

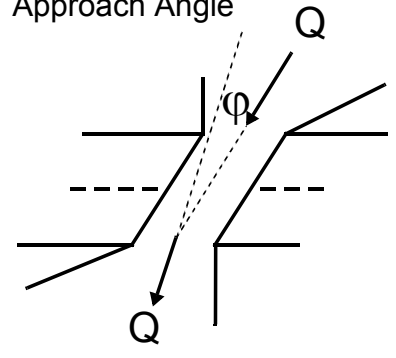

17. Channel impact zone 1 :

Where? LB (LB, RB)

Range? 90

Channel impact zone 2:

Where? RB (LB, RB)

Range? 15 feet $\underline{\mathbf{U S}}$ (US, UB, DS) to $\underline{\mathbf{1 2}}$ feet $\underline{\mathbf{U B}}$

Impact Severity: 0- none to very slight; 1- Slight; 2- Moderate; 3- Severe
16. Bridge skew: $\mathbf{5 5}$ Bridge Skew Angle

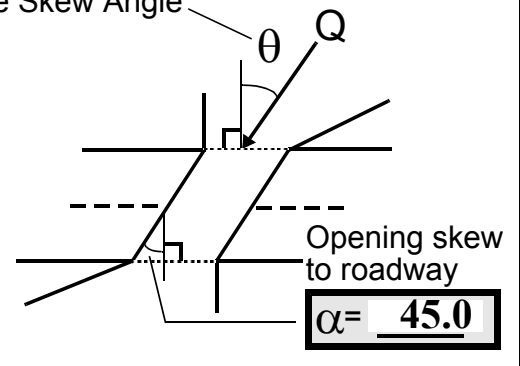

\section{Exist? $\mathbf{Y}(Y$ or $N)$}

Severity 1

, UB, DS) to $\underline{\mathbf{5 0}}$ feet $\underline{\mathbf{U S}}$

Exist? $\underline{\mathbf{Y}}(\mathrm{Y}$ or $N)$

Severity $\underline{2}$ 
18. Bridge Type: 1a

1a- Vertical abutments with wingwalls

1 b- Vertical abutments without wingwalls

2- Vertical abutments and wingwalls, sloping embankment Wingwalls parallel to abut. face

3- Spill through abutments

4- Sloping embankment, vertical wingwalls and abutments

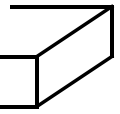

1a with wingwalls

Wingwall angle less than $90^{\circ}$.

19. Bridge Deck Comments (surface cover variations, measured bridge and span lengths, bridge type variations, approach overflow width, etc.)

4. The surface cover on the US left bank is lawn and TH 12 on the overbank with trees and brush on the immediate bank. The US right bank cover is also a lawn but nearly all forest further US with a side road that bisects the forest.

5. The channel is moderately sloping and generally riffle above $50 \mathrm{ft}$ US. Between $50 \mathrm{ft}$ US and the US bridge face, the water surface is pool and riffle. The channel is pooled under the bridge except for a small riffle at the US bridge face. The DS channel is a series of pools and riffles.

\section{Upstream Channel Assessment}

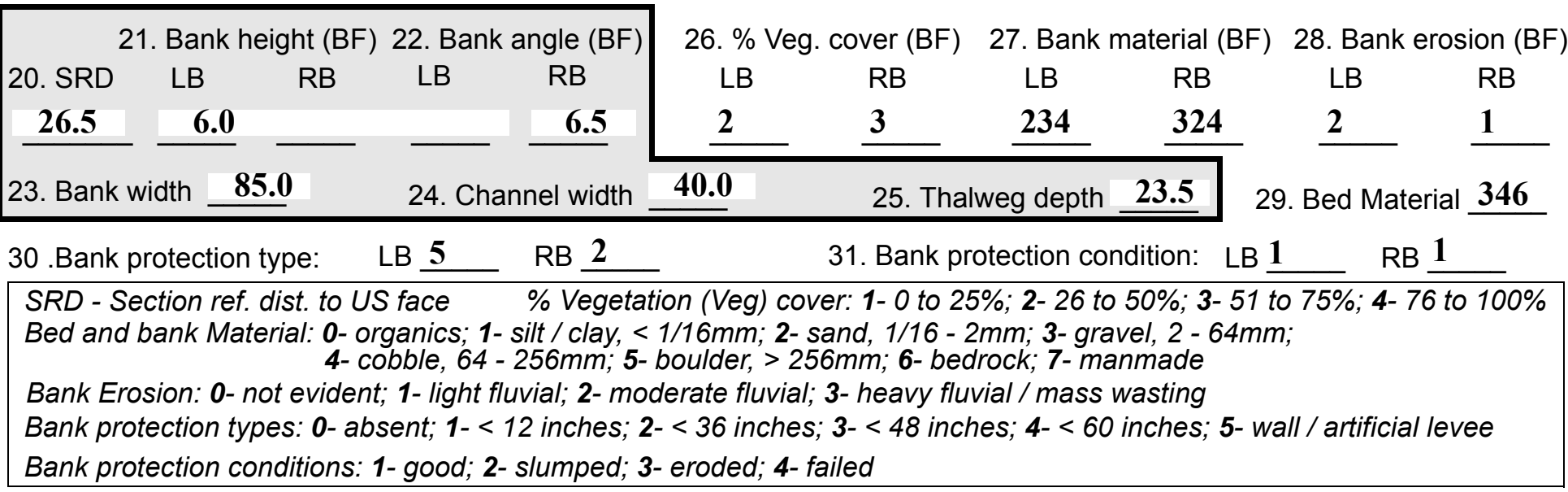

32. Comments (bank material variation, minor inflows, protection extent, etc.):

27,29. The bank and bed material noted was observed near $150 \mathrm{ft}$ US beyond the fill and retaining walls on both banks US.

28. The channel impacts the road embankment on the US left bank from $90 \mathrm{ft}$ US to $50 \mathrm{ft}$ US. The left bank is cut nearly vertical US of the retaining wall.

30. A retaining wall extends from $50 \mathrm{ft}$ US to the US end of the US left wingwall. Another retaining wall is on the right bank side from $0 \mathrm{ft}$ US to $22 \mathrm{ft}$ US which may also be considered as the US right wingwall. From $22 \mathrm{ft}$ US to $55 \mathrm{ft}$ US, stone fill protection is evident on the right bank.

The US reach is nearly straight and narrows at $50 \mathrm{ft}$ US where the left bank retaining wall begins. A bedrock outcrop at the bed elevation along the right bank side of the channel is between $25 \mathrm{ft}$ and $40 \mathrm{ft}$ US. 
36. Point bar extent: $\mathbf{8}$ feet US (US, UB) to 8 feet DS (US, UB, DS) positioned $\underline{\mathbf{0}}$ $\%$ LB to 60 $\%$ RB

37. Material: $\mathbf{3 2 4}$

38. Point or side bar comments (Circle Point or Side; Note additional bars, material variation, status, etc.):

This bar is present mostly under the bridge on the left bank side of the channel. The channel bends left into the bridge here.

39. Is a cut-bank present? $\underline{\mathbf{Y}}$ ( $Y$ or if $N$ type ctrl-n $c b)$ 40. Where? $\underline{\mathbf{L B}}$ (LB or RB)

41. Mid-bank distance: $\mathbf{6 0}$ 42. Cut bank extent: 90 US, UB) to $\underline{\mathbf{5 0}}$ feet $\underline{\mathbf{U S}}$ (US, UB, DS)

43. Bank damage: 2 (1- eroded and/or creep; 2- slip failure; 3- block failure)

44. Cut bank comments (eg. additional cut banks, protection condition, etc.):

The bank is eroded severely at the US end of the left bank retaining wall. Tree roots are holding the upper half of the bank stable, but some undermining of the bank is evident.

45. Is channel scour present? $\mathbf{N}$ (Y or if $N$ type ctrl-n cs)

47. Scour dimensions: Length Width Depth :46. Mid-scour distance: -

48. Scour comments (eg. additional scour areas, local scouring process, etc.):

\section{NO CHANNEL SCOUR}

49. Are there major confluences? $\mathbf{N}$

51. Confluence 1: Distance Confluence 2: Distance 52. Enters on Enters on 54. Confluence comments (eg. confluence name):

NO MAJOR CONFLUENCES
50. How many? -

53. Type(1- perennial; 2- ephemeral)

Type (1-perennial; 2- ephemeral) ( $(L B$ or $R B)$ ( $L B$ or $R B)$ Position $\%$ LB to $\% \mathrm{RB}$ 
65. Debris and Ice Is there debris accumulation?

(Yor $N)$ 66. Where? $\mathbf{N}$

(1- Upstream; 2- At bridge; 3- Both)

67. Debris Potential ( 1- Low; 2- Moderate; 3- High)

69. Is there evidence of ice build-up? 2

68. Capture Efficiency 1

(1-Low; 2- Moderate; 3- High)

Ice Blockage Potential $\mathbf{N}$

(1-Low; 2-Moderate; 3- High)

70. Debris and Ice Comments:

1

Overall, the channel is incised and stable with old growth trees on both banks US.

\begin{tabular}{|l|c|c|c|c|c|c|c|c|}
\hline Abutments & $\begin{array}{c}\text { 71. Attack } \\
\angle \text { (BF) }\end{array}$ & $\begin{array}{c}\text { 72. Slope } \angle \\
\text { (Qmax) }\end{array}$ & $\begin{array}{c}\text { 73. Toe } \\
\text { loc. (BF) }\end{array}$ & $\begin{array}{c}\text { 74. Scour } \\
\text { Condition }\end{array}$ & $\begin{array}{c}75 . \text { Scour } \\
\text { depth }\end{array}$ & $\begin{array}{c}\text { 76. Exposure } \\
\text { depth }\end{array}$ & 77. Material & 78. Length \\
\hline LABUT & & - & $\mathbf{9 0}$ & $\mathbf{2}$ & $\mathbf{0}$ & $\mathbf{0}$ & - & $\mathbf{9 0 . 0}$ \\
\hline RABUT & $\mathbf{2}$ & $\mathbf{1 5}$ & $\mathbf{9 0}$ & & & $\mathbf{2}$ & $\mathbf{1}$ & $\mathbf{1 2 . 5}$ \\
\hline
\end{tabular}

Pushed: $L B$ or RB

Toe Location (Loc.): 0- even, 1- set back, 2- protrudes

Scour cond.: 0- not evident; 1- evident (comment); 2- footing exposed; 3-undermined footing; 4- piling exposed; 5- settled; 6- failed

Materials: 1- Concrete; 2- Stone masonry or drywall; 3- steel or metal; 4- wood

79. Abutment comments (eg. undermined penetration, unusual scour processes, debris, etc.):

1.0

2

77. Both abutments are unmortared stone slab and block walls.

74. The flow is mainly along the right abutment and some scour is evident at the DS end. The scour hole is 28 $\mathrm{ft}$ long and $5 \mathrm{ft}$ wide at $12 \mathrm{ft}$ DS. At $8 \mathrm{ft}$ DS, the hole is $1 \mathrm{ft}$ deeper than the mean thalweg depth which is $0.5 \mathrm{ft}$. At the DS end of the right abutment a few stone slabs are pitched toward the stream where the abutment is settling into the scour hole.

80. Wingwalls:

$\begin{array}{llll} & & & \\ \text { Exist? Material? } & \text { Scour } & \text { Scour } & \text { Exposure } \\ \text { Condition? } & \text { depth? } & \text { depth? }\end{array}$

USLWW:

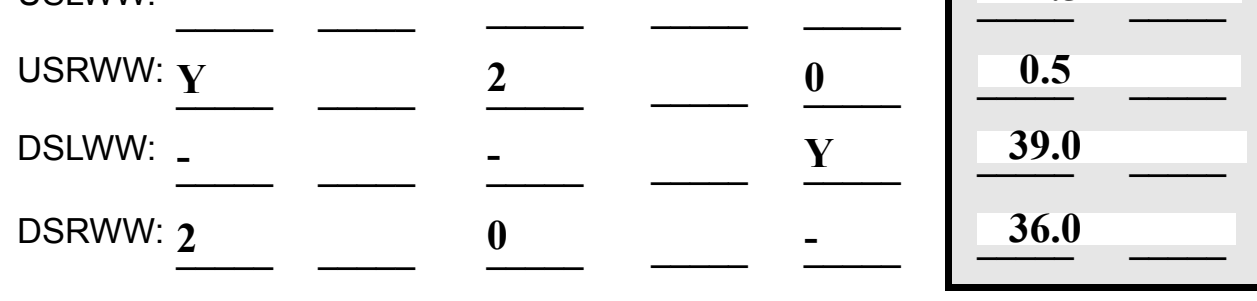

Wingwall materials: 1- Concrete; 2- Stone masonry or drywall; 3- steel or metal; 4- wood

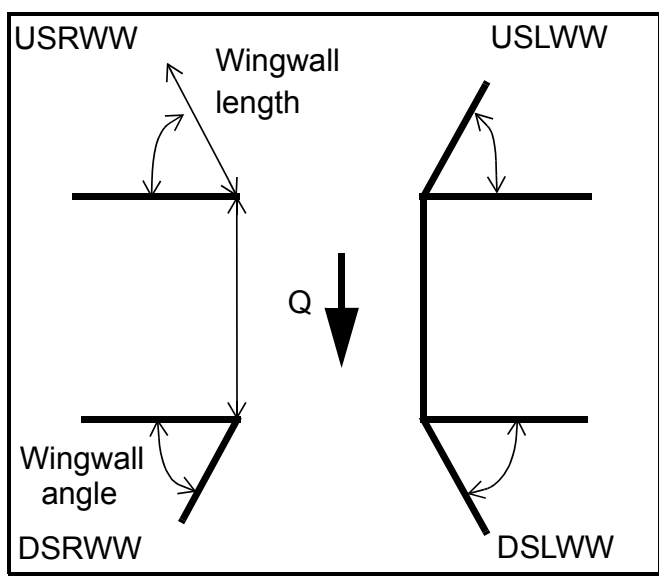

82. Bank / Bridge Protection:

\begin{tabular}{|l|l|l|l|l|l|l|c|c|}
\hline Location & USLWW & USRWW & LABUT & RABUT & LB & RB & DSLWW & DSRWW \\
\hline Type & - & $\mathbf{0}$ & $\mathbf{Y}$ & $\mathbf{1}$ & - & - & - & - \\
\hline Condition & $\mathbf{Y}$ & - & $\mathbf{1}$ & - & - & - & - & - \\
\hline Extent & $\mathbf{2}$ & - & $\mathbf{1}$ & $\mathbf{0}$ & $\mathbf{0}$ & $\mathbf{0}$ & $\mathbf{0}$ & - \\
\hline
\end{tabular}

Bank / Bridge protection types: 0- absent; 1- < 12 inches; 2- < 36 inches; 3- < 48 inches; 4- < 60 inches; 
83. Wingwall and protection comments (eg. undermined penetration, unusual scour processes, etc.):

-
-
-
-
-
0
-
-
1
1
1

\section{Piers:}

84. Are there piers? $\mathbf{8 0 .}$ ( $Y$ or if $N$ type ctrl-n pr)

\begin{tabular}{|l|l|l|l|l|l|l|l|}
\hline \multirow{2}{*}{$\begin{array}{l}85 . \\
\text { Pier no. }\end{array}$} & \multicolumn{3}{|c|}{ width (w) feet } & \multicolumn{3}{c|}{ elevation (e) feet } \\
\cline { 2 - 8 } & w1 & w2 & w3 & e@w1 & e@w2 & e@w3 \\
\hline Pier 1 & & & & $\mathbf{1 0 . 0}$ & $\mathbf{3 4 . 0}$ & $\mathbf{1 5 0 . 0}$ \\
\hline Pier 2 & & & $\mathbf{9 . 5}$ & $\mathbf{3 0 . 0}$ & $\mathbf{1 4 5 . 0}$ & $\mathbf{0 . 0}$ \\
\hline Pier 3 & & - & - & $\mathbf{2 1 . 0}$ & - & - \\
\hline Pier 4 & - & - & - & - & - & - \\
-
\end{tabular}

\begin{tabular}{|l|l|l|l|l|}
\hline Level 1 Pier Descr. & \multicolumn{1}{|c|}{1} & \multicolumn{1}{|c|}{2} & \multicolumn{1}{|c|}{3} & \multicolumn{1}{|c|}{4} \\
\hline 86. Location (BF) & The & wing- & right & con- \\
\hline 87. Type & US & wall & wing & sist- \\
\hline 88. Material & end & and & wall & ing \\
\hline 89. Shape & of & retai & is & of \\
\hline 90. Inclined? & the & ning & pro- & sand, \\
\hline 91. Attack $\angle$ (BF) & left & wall & tecte & grav \\
\hline 92. Pushed & abut & is & d & el \\
\hline 93. Length (feet) & - & - & - & - \\
\hline 94. \# of piles & ment & set- & with & and \\
\hline 95. Cross-members & cor- & tling. & eart & cob- \\
\hline 96. Scour Condition & ner & $\mathbf{8 2 . ~}$ & h & bles. \\
\hline 97. Scour depth & with & The & back & \\
\hline 98. Exposure depth & the & DS & fill & \\
\hline
\end{tabular}

LFP, LTB, LB, MCL, MCM, MCR, RB, RTB, RFP

1- Solid pier, 2- column, 3- bent

1-Wood; 2- concrete; 3- metal; 4- stone

1- Round; 2- Square; 3- Pointed

Y-yes; $N-$ no

$L B$ or $R B$

0- none; 1- laterals; 2- diagonals; 3- both

0- not evident; 1- evident (comment);

2- footing exposed; 3- piling exposed;

4- undermined footing; 5- settled; 6-failed 
99. Pier comments (eg. undermined penetration, protection and protection extent, unusual scour processes, etc.):

$\mathbf{N}$

100.

\section{E. Downstream Channel Assessment}

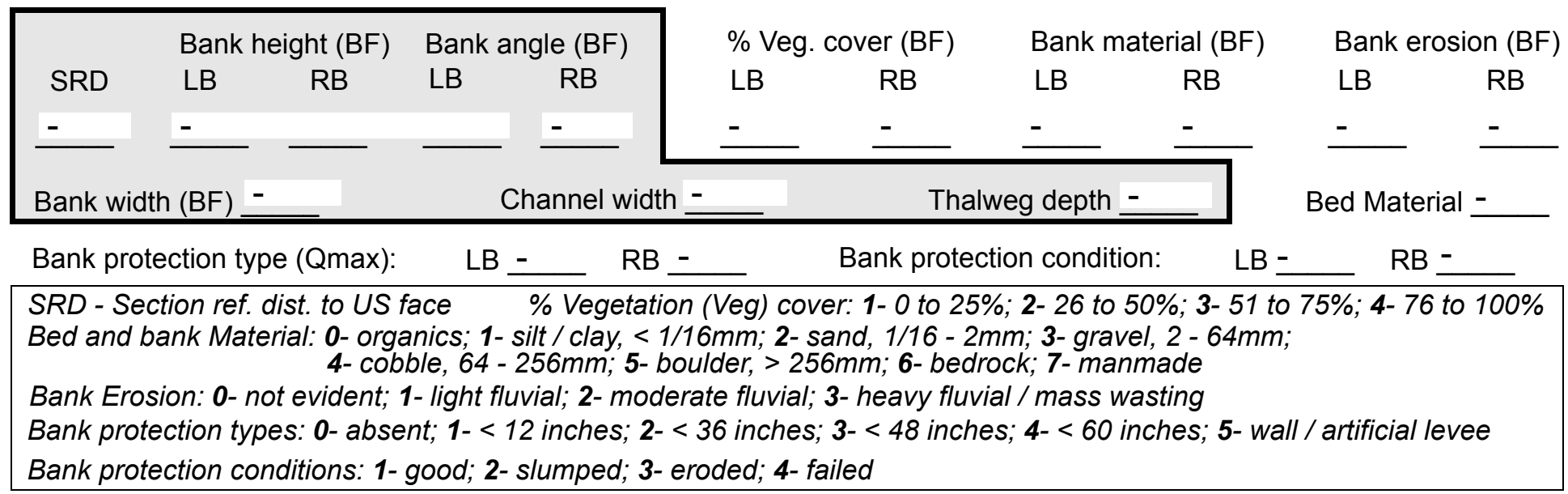

Comments (eg. bank material variation, minor inflows, protection extent, etc.):$$
-
$$$$
-
$$

$-$

$-$

$-$

$-$

$-$

$-$

$-$

$-$

$-$

$-$

$-$

$-$

$-$

\section{Is a drop structure present? __ ( $Y$ or $N$, if $N$ type ctrl-n ds) 102. Distance: ___ feet}

103. Drop: -_ feet 104. Structure material: ___ (1- steel sheet pile; 2- wood pile; 3- concrete; 4- other)

105. Drop structure comments (eg. downstream scour depth):

$-$

$-$

$-$

-

-

- 
106. Point/Side bar present? (Y or $N$. if $N$ type ctrl-n pb)Mid-bar distance:

Mid-bar width: -

Point bar extent: feet -

(US, UB, DS) to feet (US, UB, DS) positioned $\%$ LB to $\% \mathrm{RB}$ Material:

Point or side bar comments (Circle Point or Side; note additional bars, material variation, status, etc.):

$-$

\section{NO PIERS}

Is a cut-bank present?

Cut bank extent: feet (US, UB, DS) to feet Where? (LB or $R B)$ Mid-bank distance:

Bank damage: (1- eroded and/or creep; 2- slip failure; 3- block failure)

Cut bank comments (eg. additional cut banks, protection condition, etc.): 1

1

234

234

Is channel scour present? 1 (Y or if $N$ type ctrl-n cs) Mid-scour distance: 1 Scour dimensions: Length $\underline{\mathbf{3 2 4}}$ Width $\mathbf{0}$ Depth: $\mathbf{0}$ Positioned - _ \% $\%$ LB to _- $\%$ RB Scour comments (eg. additional scour areas, local scouring process, etc.):

The reach is fairly straight DS of the bridge and is moderately sloping overall. Some boulders are also present on the bed.

\section{Are there major confluences?} ( $Y$ or if $N$ type ctrl-n $m c)$

How many?

Confluence 1: Distance Enters on ( $L B$ or $R B)$

Type (1-perennial; 2- ephemeral)

Confluence 2: Distance

Enters on ( $L B$ or $R B)$

Type (1-perennial; 2- ephemeral)

Confluence comments (eg. confluence name):

\section{F. Geomorphic Channel Assessment}

107. Stage of reach evolution
1- Constructed

2- Stable

3- Aggraded

4- Degraded

5- Laterally unstable

6- Vertically and laterally unstable 
108. Evolution comments (Channel evolution not considering bridge effects; See HEC-20, Figure 1 for geomorphic descriptors): $\mathbf{N}$

$-$

NO DROP STRUCTURE

$\mathbf{N}$

-

$-$

$-$ 


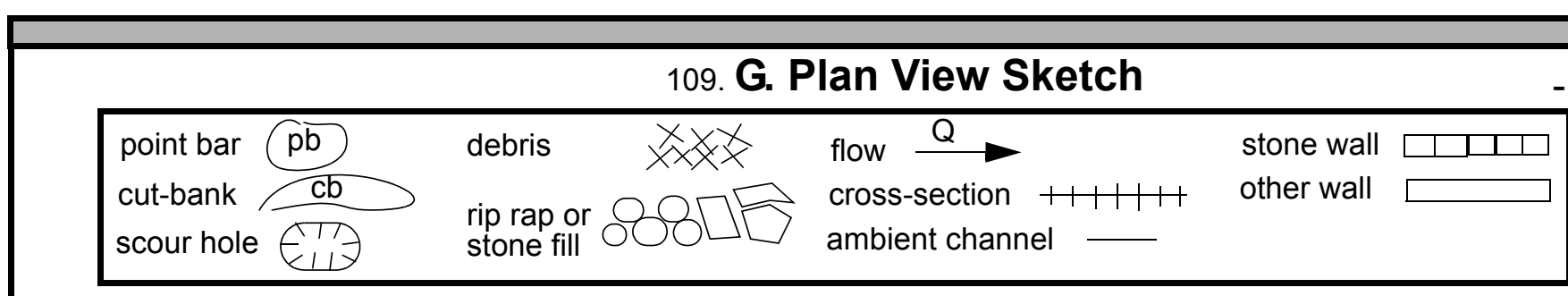


APPENDIX F:

SCOUR COMPUTATIONS 
SCOUR COMPUTATIONS

\begin{tabular}{|c|c|c|c|}
\hline Structure Number: BRATTH00120007 & & Town: & BRATTLEBORO \\
\hline Road Number: $\quad$ TH 12 & & County: & WINDHAM \\
\hline Stream: HALLADAY BROOK & & & \\
\hline Initials RLB & Checked: & ECW & \\
\hline Analysis of contraction scour, li & bed or c & lear wa & \\
\hline $\begin{array}{l}\text { Critical Velocity of Bed Material } \\
\text { VC=11.21*y1^0.1667*D50^0.33 with } \\
\text { (Richardson and Davis, 1995, p. }\end{array}$ & $\begin{array}{l}\text { converted } \\
=2.65 \\
\text { eq. } 16)\end{array}$ & to Engl & sh units) \\
\hline Approach Section & & & \\
\hline Characteristic & $100 \mathrm{yr}$ & $500 \mathrm{yr}$ & other $\mathrm{Q}$ \\
\hline Total discharge, cfs & 1580 & 2250 & 870 \\
\hline Main Channel Area, ft2 & 191 & 209 & 165 \\
\hline Left overbank area, ft2 & 9 & 52 & 0 \\
\hline Right overbank area, ft2 & 60 & 92 & 16 \\
\hline Top width main channel, ft & 27 & 27 & 27 \\
\hline Top width L overbank, ft & 23 & 109 & 0 \\
\hline Top width $\mathrm{R}$ overbank, ft & 47 & 52 & 40 \\
\hline D50 of channel, ft & 0.2186 & 0.2186 & 0.2186 \\
\hline D50 left overbank, ft & -- & -- & -- \\
\hline D50 right overbank, ft & -- & -- & -- \\
\hline $\mathrm{Y}_{1}$, average depth, $\mathrm{MC}$, ft & 7.1 & 7.7 & 6.1 \\
\hline y1, average depth, LOB, ft & 0.4 & 0.5 & $\mathrm{ERR}$ \\
\hline yl, average depth, ROB, ft & 1.3 & 1.8 & 0.4 \\
\hline Total conveyance, approach & 17671 & 22857 & 12445 \\
\hline Conveyance, main channel & 15713 & 18139 & 12226 \\
\hline Conveyance, LOB & 196 & 1339 & 0 \\
\hline Conveyance, ROB & 1761 & 3379 & 216 \\
\hline Percent discrepancy, conveyance & 0.0057 & 0.0000 & 0.0241 \\
\hline Qm, discharge, MC, cfs & 1404.9 & 1785.6 & 854.7 \\
\hline Ql, discharge, LOB, Cfs & 17.5 & 131.8 & 0.0 \\
\hline Qr, discharge, ROB, Cfs & 157.5 & 332.6 & 15.1 \\
\hline $\mathrm{Vm}$, mean velocity $\mathrm{MC}$, ft/s & 7.4 & 8.5 & 5.2 \\
\hline VI, mean velocity, LOB, ft/s & 1.9 & 2.5 & ERR \\
\hline Vr, mean velocity, ROB, ft/s & 2.6 & 3.6 & 0.9 \\
\hline Vc-m, crit. velocity, MC, ft/s & 9.4 & 9.5 & 9.1 \\
\hline Vc-l, crit. velocity, LOB, ft/s & ERR & ERR & ERR \\
\hline Vc-r, crit. velocity, ROB, ft/s & ERR & ERR & ERR \\
\hline Results & & & \\
\hline Live-bed(1) or Clear-Water(0) Cont & action $\mathrm{Scc}$ & our? & \\
\hline Main Channel & 0 & 0 & 0 \\
\hline Left Overbank & $\mathrm{N} / \mathrm{A}$ & $\mathrm{N} / \mathrm{A}$ & $\mathrm{N} / \mathrm{A}$ \\
\hline Right Overbank & $\mathrm{N} / \mathrm{A}$ & $\mathrm{N} / \mathrm{A}$ & $\mathrm{N} / \mathrm{A}$ \\
\hline
\end{tabular}


Clear water Contraction Scour in MAIN CHANNEL

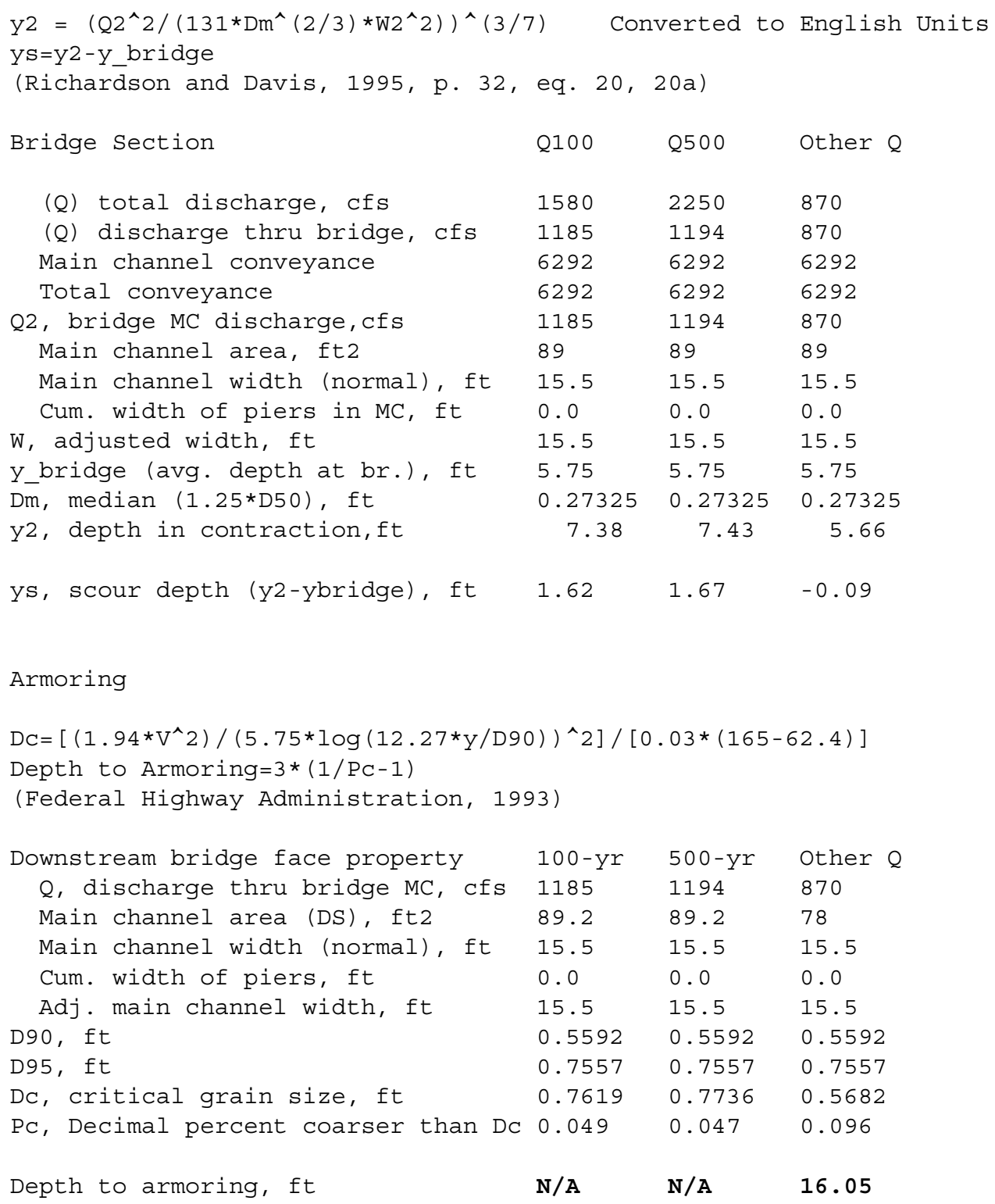




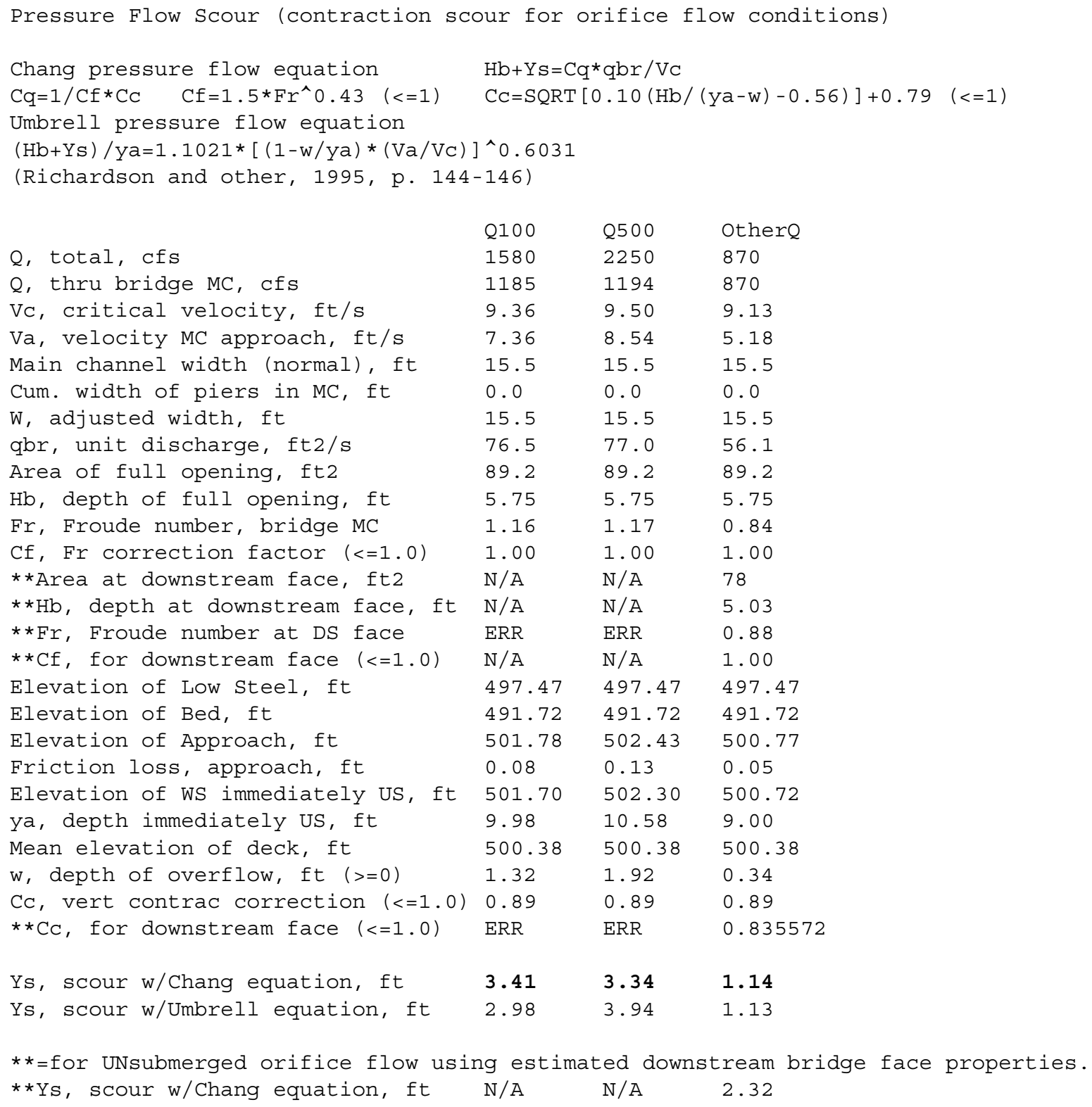




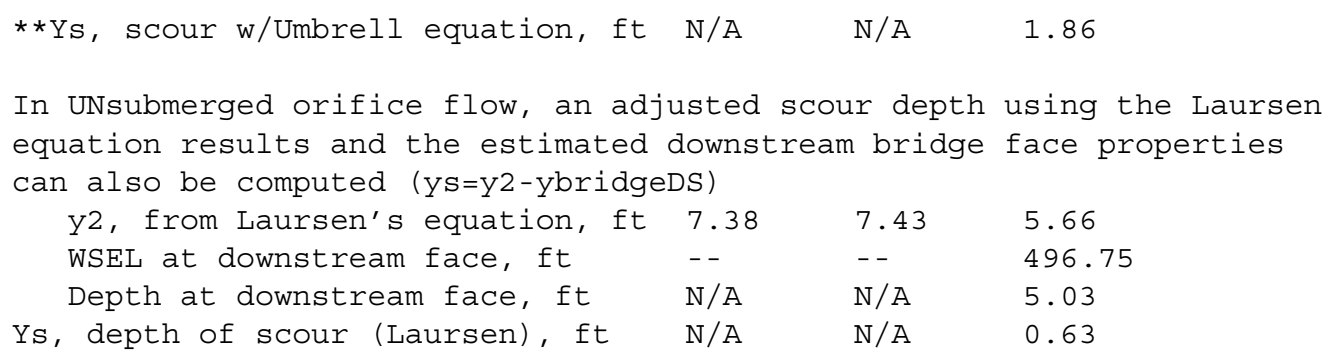

Abutment Scour

Froehlich's Abutment Scour

$\mathrm{Ys} / \mathrm{Y} 1=2.27 * \mathrm{~K} 1 * \mathrm{~K} 2 *\left(\mathrm{a}^{\prime} / \mathrm{Y} 1\right)^{\wedge} 0.43 * \mathrm{Fr} 1^{\wedge} 0.61+1$

(Richardson and others, 1995, p. 48, eq. 28)

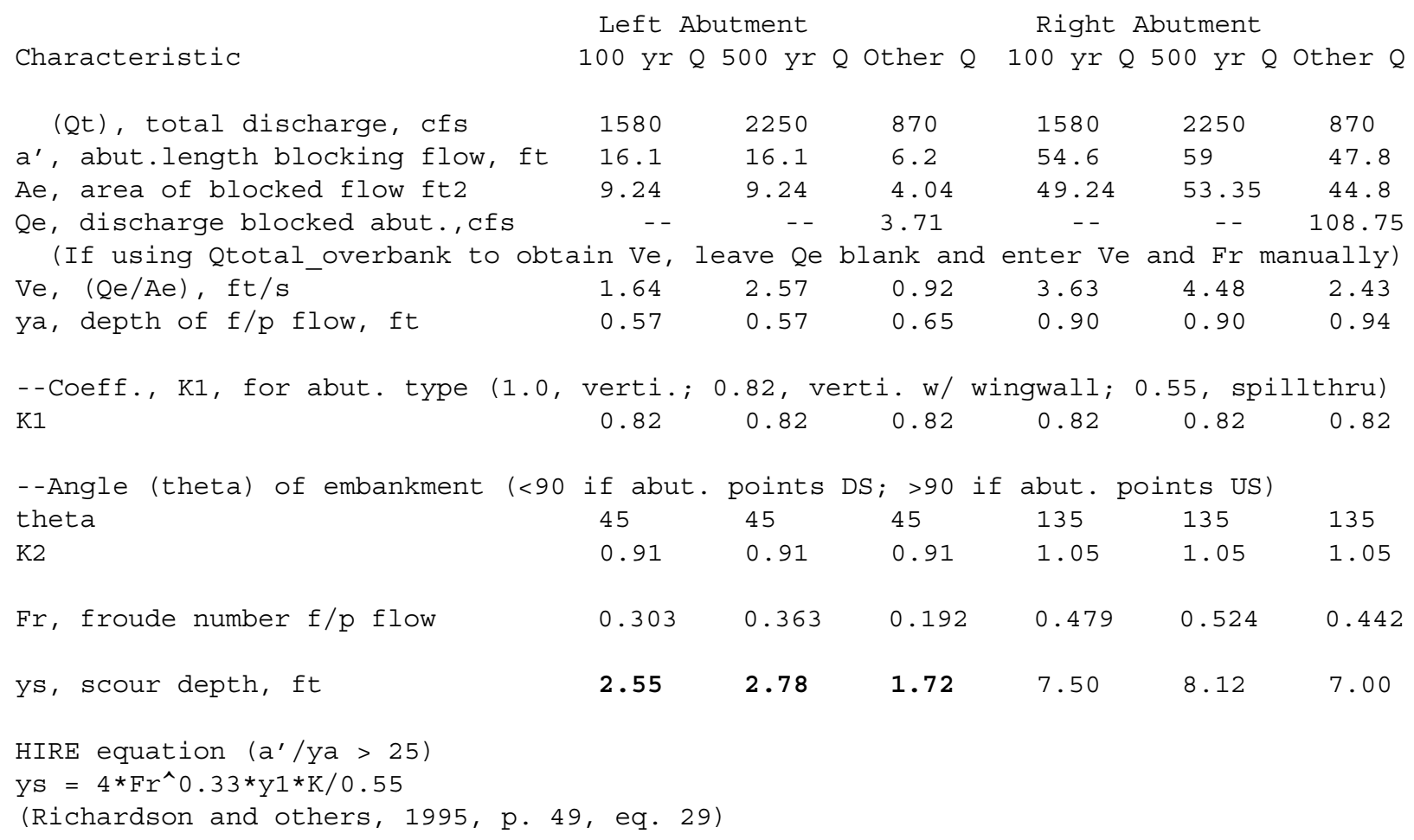




\begin{tabular}{|c|c|c|c|c|c|c|}
\hline$a^{\prime}$ (abut length blocked, ft) & 16.1 & 16.1 & 6.2 & 54.6 & 59 & 47.8 \\
\hline y1 (depth f/p flow, ft) & 0.57 & 0.57 & 0.65 & 0.90 & 0.90 & 0.94 \\
\hline$a^{\prime} / y^{1}$ & 28.05 & 28.05 & 9.51 & 60.54 & 65.25 & 51.00 \\
\hline Skew correction (p. 49, fig. 16) & 0.80 & 0.80 & 0.80 & 1.10 & 1.10 & 1.10 \\
\hline Froude no. f/p flow & 0.30 & 0.36 & 0.19 & 0.48 & 0.52 & 0.44 \\
\hline Ys w/ corr. factor $\mathrm{K} 1 / 0.55$ : & 2.25 & 2.39 & ERR & 5.66 & 5.84 & 5.73 \\
\hline vertical w/ $\mathrm{ww}^{\prime} \mathrm{s}$ & 1.85 & 1.96 & $\mathrm{ERR}$ & 4.64 & 4.79 & 4.70 \\
\hline spill-through & 1.24 & 1.31 & ERR & 3.11 & 3.21 & 3.15 \\
\hline Abutment riprap Sizing & & & & & & \\
\hline Isbash Relationship & & & & & & \\
\hline $\begin{array}{l}\mathrm{D} 50=\mathrm{Y}^{*} \mathrm{~K} * \mathrm{Fr} \mathrm{r}^{\wedge} 2 /(\mathrm{Ss}-1) \text { and } \mathrm{D} 50=\mathrm{Y} * \mathrm{~K} *( \\
\text { (Richardson and others, } 1995, \mathrm{p} 11\end{array}$ & $\begin{array}{l}\wedge \\
2) \wedge 0 \\
\text { eq. } 8\end{array}$ & $(S s-1)$ & & & & \\
\hline Characteristic & Q100 & Q500 & Other $Q$ & Q100 & Q500 & Other $\mathrm{Q}$ \\
\hline Fr, Froude Number & 1.16 & 1.17 & 0.88 & 1.16 & 1.17 & 0.88 \\
\hline$y$, depth of flow in bridge, ft & 5.75 & 5.75 & 5.03 & 5.75 & 5.75 & 5.03 \\
\hline Median Stone Diamete & left & utment & & right & abutment, & ft \\
\hline Fr $<=0.8$ (vertical abut.) & ERR & ERR & ERR & ERR & ERR & ERR \\
\hline Fr>0.8 (vertical abut.) & 2.51 & 2.51 & 2.03 & 2.51 & 2.51 & 2.03 \\
\hline
\end{tabular}

